\title{
Mixed molybdenum and vanadium oxide nanoparticles with excellent high-power performance as Li-ion battery negative electrodes
}

\author{
Dustin Bauer a, b, Thomas E. Ashton a, Dan J.L. Brett ${ }^{\text {c, }}$ Paul R. Shearing ${ }^{\text {, }}$, \\ Noriyoshi Matsumi ${ }^{\mathrm{b}}$, Jawwad A. Darr ${ }^{\mathrm{a},}{ }^{*}$ \\ a Department of Chemistry, University College London, 20 Gordon Street, London, WC1H OAJ, UK \\ b School of Materials Science, Japan Advanced Institute of Science and Technology, 1-1 Asahidai, Nomi, Ishikawa, Japan \\ c Electrochemical Innovation Lab, Department of Chemical Engineering, University College London, Torrington Place, London, WC1E 7JE, UK
}

\section{A R T I C L E I N F O}

\section{Article history:}

Received 10 June 2019

Received in revised form

26 July 2019

Accepted 12 August 2019

Available online 13 August 2019

\section{Keywords:}

Continuous hydrothermal flow synthesis

Molybdenum-vanadium oxide

Nanoparticles

Solid solution

Li-ion battery

\begin{abstract}
A B S T R A C T
Several nano-sized mixed molybdenum/vanadium oxide monoclinic solid solutions were synthesised using a continuous hydrothermal flow process and studied with a wide range of physical characterization techniques including X-ray photoelectron spectroscopy, X-ray diffraction, transmission electron microscopy and X-ray absorption spectroscopy. The nanomaterials were tested as anodes for Li-ion batteries in the potential range $0.05-3.00 \mathrm{~V}$ vs. $\mathrm{Li} / \mathrm{Li}^{+}$. Samples with nominal formulas of $\mathrm{Mo}_{0.5} \mathrm{~V}_{0.5} \mathrm{O}_{2}$ and $\mathrm{Mo}_{0.33} \mathrm{~V}_{0.67} \mathrm{O}_{2}$ showed excellent performance, especially at high current rates, due to their highly pseudocapacitive charge storage mechanism. At a specific current of $10 \mathrm{Ag}^{-1}, \mathrm{Mo}_{0.5} \mathrm{~V}_{0.5} \mathrm{O}_{2}$ and $\mathrm{Mo}_{0.33} \mathrm{~V}_{0.67} \mathrm{O}_{2}$ showed specific capacities of ca. 200 and $170 \mathrm{mAh} \mathrm{g}{ }^{-1}$, respectively. $\mathrm{Mo}_{0.5} \mathrm{~V}_{0.5} \mathrm{O}_{2}$ also showed good cyclability, with a specific capacity of $480 \mathrm{mAh} \mathrm{g}^{-1}$ after 150 cycles at a specific current of $0.5 \mathrm{Ag}^{-1}$. For cyclic voltammetries conducted at high scan rates, pseudocapacitive charge storage contributed more than $90 \%$ to the total charge storage for both samples. The scalability of the synthesis technique and excellent electrochemical performance at high power, make these materials promising as negative electrode active materials for Li-ion batteries.
\end{abstract}

() 2019 Published by Elsevier Ltd. This is an open access article under the CC BY license (http:// creativecommons.org/licenses/by/4.0/).

\section{Introduction}

Due to rising interest in renewable energy harvesting and storage, (hybrid) electric vehicles, and portable electronics, research and development of secondary Li-ion batteries (LIBs) is becoming increasingly important [1]. LIBs are the most widespread energy storage technology in portable devices, mainly due to their superior energy densities [2]. Many current LIBs share a design similar to that of the first commercial LIBs sold by Sony in 1991. They are made up of graphite anodes, $\mathrm{LiCoO}_{2}$ (or similar intercalation material) cathodes, an electronically insulating separator (polyethylene) that physically separates the two electrodes, and an organic $\mathrm{Li}^{+}$electrolyte [3].

There are a number of challenges with using graphite as the anode material, which includes poor rate performance [4], safety issues due to lithium plating and dendrite formation (which can

\footnotetext{
* Corresponding author.

E-mail address: j.a.darr@ucl.ac.uk (J.A. Darr).

URL: http://www.ucl.me.uk.
}

cause cell failure) [5], and irreversible capacity loss caused by the formation of a solid electrolyte interphase (SEI) required for stable cycling $[4,5]$.

Due to their superior rate properties, metal oxide nanoparticles have been studied as active materials for LIB negative electrodes. Pseudocapacitive metal oxide nanoparticles with high surface areas are of special interest. Pseudocapacitance stems from fast, highly reversible Faradaic reactions [6,7]. Such charge storage has been shown to occur in many active nano-sized Li-ion electrodes, such as nano-sized $\mathrm{TiO}_{2}$ polymorphs (undoped and doped anatase [8,9], $\mathrm{TiO}_{2}(\mathrm{~B})$ and $\mathrm{TiO}_{2}$ bronze [10]), $\mathrm{VO}_{2}$ [11], and $\mathrm{MoO}_{2}$ [6,12]. For these materials the pseudocapacitive behaviour depended on high surface area (extrinsic pseudocapacitance), hence it was a result of electrode/material design [13].

Both molybdenum and vanadium dioxides have been studied as anodes for LIBs due to their comparatively high abundance, high specific capacities and relatively low cost [11,14-16]. The theoretical capacity of $\mathrm{MoO}_{2}$ is $838 \mathrm{mAh} \mathrm{g}^{-1}$ [17], and that of $\mathrm{VO}_{2}$ is 320 $\mathrm{mAh} \mathrm{g}^{-1}$ [18]. It has also been shown that mixed-valence state vanadium and molybdenum oxides can be advantageous due to a 
variety of readily available redox couples [19]. As for other active redox metal oxides, large volume changes during cycling can lead to capacity fading, which limits the practicality of these materials in Li-ion batteries [20].

The lithiated mixed vanadium-molybdenum oxide $\mathrm{LiVMoO}_{6}$ has been reported as a promising anode material in LIBs, displaying high capacities and good rate capability. It showed a reversible capacity of $285 \mathrm{mAh} \mathrm{g}^{-1}$ at a specific current of $5 \mathrm{Ag}^{-1}$ and 900 $\mathrm{mAh} \mathrm{g}^{-1}$ at a specific current of $0.1 \mathrm{Ag}^{-1}$. This excellent performance was attributed to the availability of multiple redox couples for $\mathrm{Li}^{+}$accommodation, via reversible redox reactions between $\mathrm{V}(\mathrm{V})$ and $\mathrm{V}(\mathrm{II})$ and between $\mathrm{Mo}(\mathrm{VI})$ and $\mathrm{Mo}(0)$ [21]. Zhao et al. synthesised a 3D hybrid of amorphous $\mathrm{VO}_{\mathrm{x}}, \mathrm{MoO}_{\mathrm{y}}$, and carbon. The material was reported to possess reversible capacities of $1705 \mathrm{mAh}$ $\mathrm{g}^{-1}$ at $0.1 \mathrm{~A} \mathrm{~g}^{-1}$ and $740 \mathrm{mAh} \mathrm{g}{ }^{-1}$ at $2 \mathrm{Ag}^{-1}$. The authors claimed that the outstanding performance was due to the amorphisation as well as the hybridization of the mixed $\mathrm{VO}_{\mathrm{x}} / \mathrm{MoO}_{\mathrm{y}} / \mathrm{C}$ material [22]. Monoclinic $\mathrm{MoO}_{2}$ has shown specific capacities of 139,126 , and 60 $\mathrm{mAh} \mathrm{g}^{-1}$ at specific currents of $0.05,0.10$, and $1.0 \mathrm{Ag}^{-1}$ [23]. When cycled in a wider potential window and hence undergoing conversion reactions, a $\mathrm{MoO}_{2}$-graphene material showed an initial specific capacities of 1000 and $806 \mathrm{mAh} \mathrm{g}^{-1}$ at specific currents of ca. 0.05 and $0.5 \mathrm{~A} \mathrm{~g}^{-1}$, respectively; but these specific capacities fell to 672 and $445 \mathrm{mAh} \mathrm{g}^{-1}$ after 100 cycles, respectively [24]. A similar $\mathrm{MoO}_{2}$-graphene oxide material showed a specific capacity of ca. $600 \mathrm{mAh} \mathrm{g}^{-1}$ at a specific current of $0.80 \mathrm{Ag}^{-1}$ [25]. Mixed oxidation state molybdenum oxides $\left(\mathrm{MoO}_{2} / \mathrm{MoO}_{3}\right.$ hybrids) have been shown to exhibit excellent performance at high rates, with a specific capacity of ca. $500 \mathrm{mAh} \mathrm{g}^{-1}$ at $2 \mathrm{Ag}^{-1}$ [26].

In comparison, monoclinic $\mathrm{VO}_{2}$ nanowires have been reported with specific capacities of 200 and $118 \mathrm{mAh} \mathrm{g}^{-1}$ at 0.1 and $1.0 \mathrm{~A} \mathrm{~g}^{-1}$, respectively. The same authors also reported hollow microspheres with a specific capacity of $163 \mathrm{mAh} \mathrm{g}^{-1}$ at $1.0 \mathrm{Ag}^{-1}$ [27]. Similarly, $\mathrm{VO}_{2}$ nanoribbons have been reported with a specific capacity of 460 $\mathrm{mAh} \mathrm{g}^{-1}$ at $0.1 \mathrm{~mA}$, which fell to $200 \mathrm{mAh} \mathrm{g}^{-1}$ after 200 cycles. By using a $\mathrm{VO}_{2}$ /graphene composite, the capacity was stabilised at 380

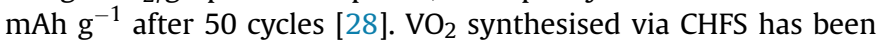
reported to show specific capacities of 255 and $95 \mathrm{mAh} \mathrm{g}^{-1}$ at specific capacities of 1 and $10 \mathrm{~A} \mathrm{~g}^{-1}$ [11].

The synthesis of nanomaterials and hybrids can often be limited in terms of scalability, reaction times and multi-step requirements. Continuous Hydrothermal Flow Synthesis (CHFS) has previously been shown to combat these issues, allowing the gram to kilogram scale production of nanomaterials in a single, rapid step [29]. The authors have previously demonstrated the use of the CHFS for use in a wide array of energy applications including Li-ion [8,9,30-35] and Na-ion [31] batteries. The ability of CHFS to consistently produce nanomaterials is extremely attractive for energy applications, which have shown increased electrochemical performance with smaller particle dimensions in many cases [36]. This is usually due to higher pseudocapacitive charge storage contributions and improved $\mathrm{Li}^{+}$dynamics. The $\mathrm{VO}_{2} / \mathrm{MoO}_{2}$ structures are especially expected to benefit from miniaturisation of particle dimensions due to increased availability of both intercalation routes (arising from the channelled structures; Supplementary Information S1) and increased availability of pseudocapacitive charge storage sites (from an increased surface area to volume ratio). Indeed, both $\mathrm{VO}_{2}$ and $\mathrm{MoO}_{2}$ have previously shown enhancement in their electrochemical performance through nanosizing, and it is expected that the mixtures and solid-solutions thereof, will also benefit $[6,16,27,37]$.

Herein, we used a CHFS process to synthesise solid solutions of nanoparticles of $\mathrm{MoO}_{2}$ and $\mathrm{VO}_{2}$, scalably under flow. The assynthesised materials showed excellent performance as anodes in LIBs.

\section{Experimental section}

\subsection{Synthesis}

$\mathrm{VO}_{2}, \mathrm{MoO}_{2}$, and mixed molybdenum/vanadium oxide nanoparticles were synthesized using a CHFS process. The authors' CHFS process has previously been described at lab scales [29,38-40] and pilot scales [41]. In the lab-scale process used herein, a feed of supercritical water (above the critical temperature $T_{c}=374{ }^{\circ} \mathrm{C}$ and pressure $p_{c}=22.1 \mathrm{MPa}$ of water) was mixed with an ambient temperature flow of aqueous metal salts in a co-current Confined Jet Mixer (CJM) made from widely available Swagelok ${ }^{\mathrm{TM}}$ parts [42]. In our current process design, after the first CJM (mixing temperature was $335^{\circ} \mathrm{C}$ ), a second CJM was used in which the hot nanoparticle slurry entered the CJM via an inner pipe, whereupon it was mixed with a quench flow of room-temperature DI water (see Fig. 1). This resulted in instant dilution and cooling of the nanoparticle slurry to $180^{\circ} \mathrm{C}$, before the slurry was further cooled in a pipe-in-pipe heat exchanger [43].

The synthesis conditions for the samples can be found in Table S1 in the Electronic Supplementary Information (ESI), including heater temperature, the concentration of precursors, calculated residence times and method of clean-up and freezedrying. The as-synthesised, freeze-dried powders were used without further treatment and were obtained as free-flowing powders. The samples are referred to by their nominal compositions throughout.

\subsection{Physical characterization}

The powders were characterised via Powder X-ray diffraction (PXRD) in a $2 \theta$ range (Mo-K $\alpha$ radiation, $\lambda=0.7107 \AA$ ) from 10 to $30^{\circ}$, with a step size of $0.5^{\circ}$ and a step time of $20 \mathrm{~s}$ on a STOE StadiP diffractometer. X-ray diffraction patterns of lithiated and delithiated electrodes were collected on a Rigaku MiniFlex 600 diffractometer (Tokyo, Japan) with a rotational velocity of $10^{\circ}$ $\min ^{-1}$ using $\mathrm{Cu}-\mathrm{K} \alpha$ radiation $(\lambda=1.5406 \AA)$, in a $2 \theta$ range of $20-80^{\circ}$.

Transmission electron microscopy (TEM) was performed on a JEOL JEM 2100 with a $\mathrm{LaB}_{6}$ filament. TEM images were analysed to determine size and particle morphology. Image capture used a Gatan Orius digital camera. Samples were dispersed in methanol via ultrasonication and pipetted onto 300-mesh copper film grid (Agar Scientific, Stansted, UK). Energy dispersive X-ray spectroscopy (EDX) was performed on a JEOL JEM 2100 for elemental analysis and mapping.

X-ray photoelectron spectroscopy (XPS) was performed to analyse valence states of metal ions, using a Thermo Scientific K-

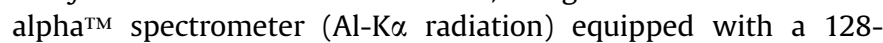
channel position sensitive detector. High-resolution regional scans for molybdenum, vanadium and oxygen were conducted at $50 \mathrm{eV}$. CasaXPSTм software (version 2.3.16) was used to process the XPS data, calibrating the spectra using the $C 1 \mathrm{~s}$ peak at $284.8 \mathrm{eV}$.

The specific surface areas of the nanoparticles were determined using Brunauer-Emmett-Teller (BET) surface area measurements. BET was performed using a Micrometrics Tristar II with liquid $\mathrm{N}_{2}$. The samples were degassed at $120^{\circ} \mathrm{C}$ for $12 \mathrm{~h}$ using $\mathrm{N}_{2}$ before measurements.

Both Mo and V K-edge X-ray absorption spectroscopy (XAS) studies were carried out on beamline B18 at Diamond Light Source (Rutherford Appleton Lab, Harwell, UK). A Si (111) monochromator was used for XAS in the ranges $19800-21000 \mathrm{eV}$ and 5265-6300 eV for Mo and V K-edges, respectively. Pellets were diluted with cellulose and data collected in transmission mode. The data was processed with the Athena software package. 


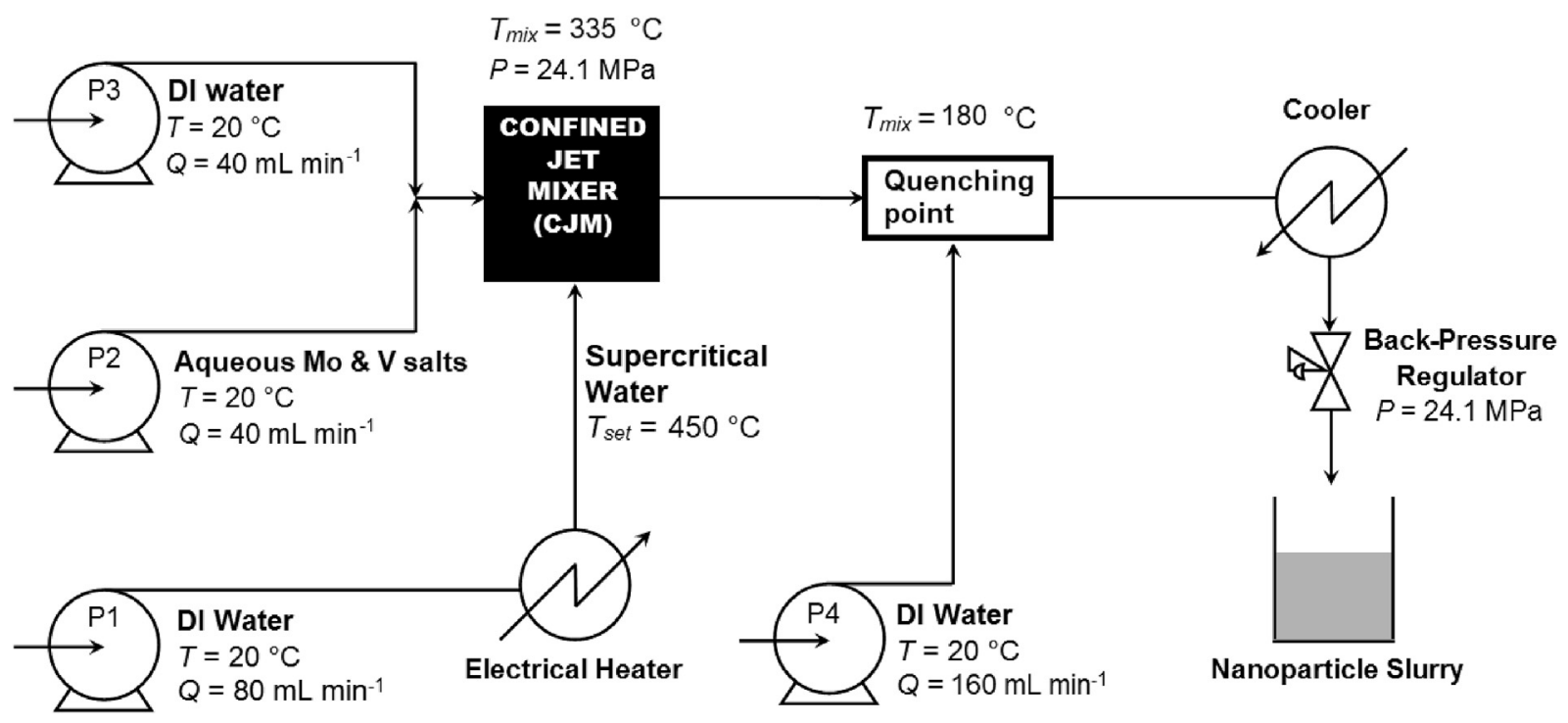

Fig. 1. Schematic of the reactor used for the continuous hydrothermal flow synthesis with quench flow. Adapted from Ref. [40].

\subsection{Electrochemical characterization}

The anodes were prepared by pre-mixing of the as-synthesised metal oxide active materials with a Super P conductive carbon (Alfa Aesar, Heysham, UK). The pre-mixed powders were then mixed with a polymeric binder (polyvinylidene fluoride, PVDF, PI-KEM, Staffordshire, UK) in a ratio of 80:10:10 wt \%. The binder was added as a pre-dissolved $10 \mathrm{wt} \%$ solution in $\mathrm{N}$-methyl-2pyrrolidone (NMP, Sigma Aldrich, Dorset, UK). A viscous slurry was achieved by using additional NMP (ca. $2.5 \mathrm{~mL}$ ). This slurry was ball-milled at $800 \mathrm{rpm}$ for $1 \mathrm{~h}$ and cast on a copper current collector ( $9 \mu \mathrm{m}$ foil, PI-KEM, Staffordshire, UK). The electrode sheets were dried on a hotplate at ca. $150{ }^{\circ} \mathrm{C}$ for $10 \mathrm{~min}$ and then left to dry overnight at room temperature. Electrodes were cut out and dried overnight under vacuum at $90^{\circ} \mathrm{C}$ in the antechamber of a glovebox before being introduced into the Ar-filled glovebox $\left(\mathrm{H}_{2} \mathrm{O}\right.$ and $\mathrm{O}_{2}<1 \mathrm{ppm}$ ) for cell assembly. The active mass loading of the anodes was in the range $1.5-2.5 \mathrm{mg} \mathrm{cm}^{-2}$. The thickness of the dried electrodes was in the range 35 to $45 \mu \mathrm{m}$.

All Li-ion half-cell testing was carried out using CR2032 coin cells. Whatman GF/D glass microfiber (Buckinghamshire, UK) was cut into discs (20 mm diameter) and acted as the separator. Separators were drenched with an organic electrolyte $\left(1 \mathrm{M} \mathrm{LiPF}_{6}\right.$ in $1: 1 \mathrm{vol}$ ratio ethylene carbonate/ethyl methyl carbonate, BASF, Ludwigshafen, Germany). Lithium metal discs (PI-KEM, Staffordshire, UK) were used as both the reference and counter electrode. The galvanostatic charge/discharge cycling was carried out using an Arbin Instrument Model BT-2000 battery tester (Caltest Instruments Ltd, Guildford, UK) at room temperature of ca. $20^{\circ} \mathrm{C}$. The tests were carried out in the potential range $0.05-3.0 \mathrm{~V} \mathrm{vs}$. $\mathrm{Li} / \mathrm{Li}^{+}$, at specific currents in the range $0.1-10.0 \mathrm{Ag}^{-1}$. Long-term cycling tests were performed at $0.25 \mathrm{~A} \mathrm{~g}^{-1}$ for 150 cycles. Cyclic voltammetry $(\mathrm{CV})$ for the half-cells was recorded in the potential window $0.05-3.0 \mathrm{~V}$ vs. $\mathrm{Li} / \mathrm{Li}^{+}$, at scan rates in the range $0.1-100.0 \mathrm{mV} \mathrm{s}^{-1}$.

Electrochemical impedance spectroscopy (EIS) was performed on an Interface 1000 Gamry potentiostat (Gamry Instruments, Pennsylvania, US) in the frequency range $100 \mathrm{kHz}$ to $50 \mathrm{mHz}$ with an AC voltage of $0.01 \mathrm{~V}$ rms on CR2032 coin cells. Staircase Potentio Electrochemical Impedance Spectroscopy (SPEIS) was performed on Swagelok-type half-cells using a Bio-Logic VSP-300 potentiostat (Bio-Logic Science Instruments, France) in the potential window
$0.05-3.0 \mathrm{~V}$ vs. $\mathrm{Li} / \mathrm{Li}^{+}$with an excitation potential of $0.01 \mathrm{~V}$ rms in the frequency range of $100 \mathrm{kHz}$ to $10 \mathrm{mHz}$. After each change in potential, there was a holding step to allow the current to fall below $1 \mathrm{~mA}$ to account for electrochemical relaxation. EIS was also conducted to calculate the diffusion coefficient in the wider frequency range $100 \mathrm{kHz}$ to $1 \mathrm{mHz}$.

Galvanostatic Intermittent Titration Technique (GITT) was used to determine diffusion coefficients using an Interface 1000 Gamry potentiostat (Gamry Instruments, Pennsylvania, US). Current pulses of $0.1 \mathrm{~A} \mathrm{~g}^{-1}$ were applied for $10 \mathrm{~min}$, followed by OCV relaxation steps of $10 \mathrm{~min}$, for both lithiation and delithiation in the potential window $0.05-3.0 \mathrm{~V}$ vs. $\mathrm{Li} / \mathrm{Li}^{+}$, two initial lithiations and delithiation via galvanostatic cycling at $0.1 \mathrm{~A} \mathrm{~g}^{-1}$.

\section{Results and discussion}

\subsection{Physical characterization}

As-prepared nanomaterials were recovered as black powders. The rate of synthesis of the nanoparticles was in the range of 20-30 $\mathrm{g} \mathrm{h}^{-1}$ for all samples. The Powder X-ray diffraction (PXRD) pattern for $\mathrm{MoO}_{2}$ was a good match to ICDS no. 23722 for monoclinic $\mathrm{MoO}_{2}$ (space group $\mathrm{P} 2_{i / c}$ ), with major peaks corresponding to the $(011)$ and $(-211)$ peaks for $\mathrm{MoO}_{2}\left(2 \theta=11.9\right.$ and $16.7^{\circ}$, respectively, see Fig. 2). For $\mathrm{VO}_{2}$, the pattern was a good match to ICDS reference pattern 34033 , and the peaks became sharper with an increase in molybdenum concentration (suggesting the materials were increasingly crystalline). The major peaks corresponded to the (011), (101) and (211) planes for monoclinic $\left(\mathrm{M}_{1}\right) \mathrm{VO}_{2}(2 \theta=12.7$, 16.9 and $24.7^{\circ}$ ). For the heterometallic oxides, the patterns became sharper as the molybdenum concentration increased. There was a shift of the (001) peak towards lower $2 \theta$ values as more Mo was added to the mixed samples, from $12.7\left(\mathrm{VO}_{2}\right)$ to $11.9^{\circ}\left(\mathrm{MoO}_{2}\right)$. The same trend was observed to a lesser degree for the peaks around $2 \theta=16.8^{\circ}$, but most obvious for the (211) peaks at $2 \theta=24.7$ and $24.0^{\circ}$ for $\mathrm{VO}_{2}$ and $\mathrm{MoO}_{2}$, respectively. The peak shift followed changes in molar concentrations of molybdenum and vanadium due to a combination of unit cell expansion/contraction (Vegard's law) and conversion from an $\mathrm{MoO}_{2}$ to a $\mathrm{VO}_{2}$ structure with increasing $\mathrm{V}$ [44].

The XRD patterns for all samples which contained at least 10 at\% 


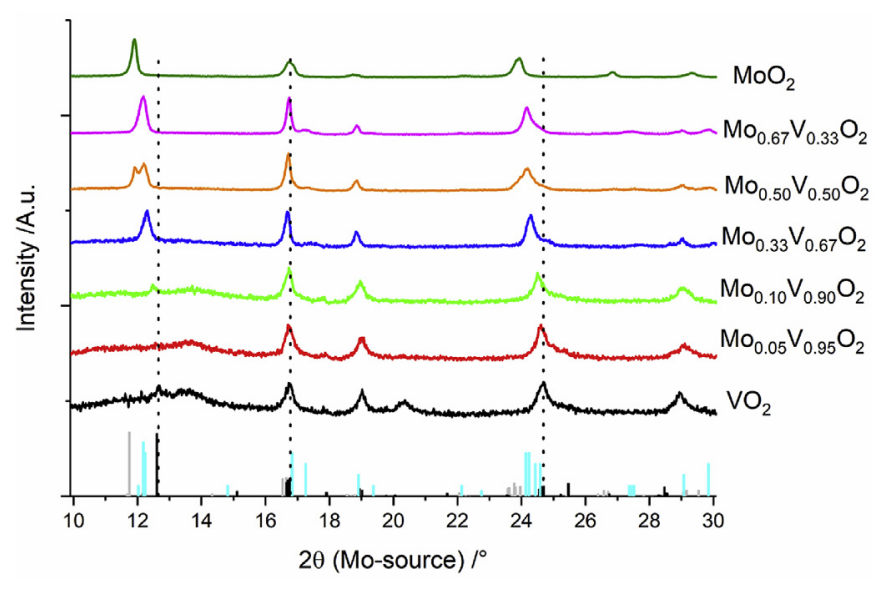

Fig. 2. X-ray diffraction patterns for all samples, along with reference patterns for monoclinic $\mathrm{VO}_{2}$ (ICDS 34033, black bars), monoclinic $\mathrm{V}_{0.33} \mathrm{Mo}_{0.67} \mathrm{O}_{2}$ (JCPDS no. 030-0849, cyan bars), and monoclinic $\mathrm{MoO}_{2}$ (ICDS 23722, grey bars). (For interpretation of the references to colour in this figure legend, the reader is referred to the Web version of this article.)

Mo and 33 at\% V, also showed similarity with the pattern of a monoclinic $\left(\mathrm{M}_{2}\right)$ phase of mixed molybdenum vanadium oxide with the composition $\mathrm{V}_{0.33} \mathrm{Mo}_{0.67} \mathrm{O}_{2}$ (JCPDS no. 030-0849) [45-47]. Polyhedral models of the $\mathrm{MoO}_{2}$ (M1), $\mathrm{VO}_{2}$ (M1), and $\mathrm{VO}_{2}$ (M2) phases are shown in Supplementary Information (see Fig. S1). Whilst the authors who originally reported the $\mathrm{M}_{2}$ phase, only observed it at vanadium concentrations in the range 33 to 55 at\%, it appeared to be present for a much wider range of vanadium concentrations in these samples, as could be indicated by the small peaks around $2 \theta=17.2$ and $29.7^{\circ}$ for $\mathrm{Mo}_{0.67} \mathrm{~V}_{0.33} \mathrm{O}_{2}, \mathrm{Mo}_{0.5} \mathrm{~V}_{0.5} \mathrm{O}_{2}$, and $\mathrm{Mo}_{0.33} \mathrm{~V}_{0.67} \mathrm{O}_{2}$.

The XRD pattern for the sample with nominal composition $\mathrm{Mo}_{0.5} \mathrm{~V}_{0.5} \mathrm{O}_{2}$, showed splitting of the (011) peak, suggesting a mixture of $\mathrm{MoO}_{2}$ and $\mathrm{VoO}_{2}$ rich phases were formed (which were potentially doped with the other element). Thus, there appears to be a limit in the solubility of $\mathrm{V}$ in the $\mathrm{MoO}_{2}$ structure, located between the nominal compositions $\mathrm{Mo}_{0.67} \mathrm{~V}_{0.33} \mathrm{O}_{2}$, to $\mathrm{Mo}_{0.5} \mathrm{~V}_{0.5} \mathrm{O}_{2}$. Likewise, the limit of solubility for Mo in the $\mathrm{VO}_{2}$ structure was expected to be in the range of compositions $\mathrm{Mo}_{0.33} \mathrm{~V}_{0.67} \mathrm{O}_{2}$, to $\mathrm{Mo}_{0.5} \mathrm{~V}_{0.5} \mathrm{O}_{2}$.

X-ray photoelectron spectroscopy (XPS) was used to determine oxidation states and semi-quantitative concentrations of molybdenum and vanadium. The $\mathrm{V} 2 p$ level binding energies revealed two peaks at 517.3 and $524.6 \mathrm{eV}$, respectively, in agreement with previous results for $V(V)$ (spin-orbit splitting of $7.3 \mathrm{eV}$ ) [48]. The intensities of the peaks for vanadium decreased in intensity with reduced vanadium concentration (see Fig. S2a). The centre of the peak in the $\mathrm{O} 1 \mathrm{~s}$ patterns for all samples was at ca. $530.6 \mathrm{eV}$ (see Fig. S2b), which was consistent with metal-oxygen bonds (V-O and Mo-O) $[22,49]$. For the Mo $3 d$ level binding energies, the peak intensities increased with increasing molybdenum concentration (see Fig. S2c). Two peaks were present for all samples containing molybdenum except pure $\mathrm{MoO}_{2}$. Those peaks were centred at 232.7 and $236.8 \mathrm{eV}$, with a spin-orbit splitting of $4.1 \mathrm{eV}$, which was consistent with $\mathrm{Mo}(\mathrm{VI})$ oxidation state [50]. For the pure $\mathrm{MoO}_{2}$, mixed $\mathrm{Mo}(\mathrm{IV}), \mathrm{Mo}(\mathrm{V})$, and $\mathrm{Mo}(\mathrm{VI})$ valence states were observed, possibly due to surface oxidation [51].

A semi-quantitative analysis of the areas of the XPS spectra for all samples yielded a good correlation between nominal concentrations of molybdenum and vanadium used for the syntheses and the concentrations found on the surfaces (see Fig. S3).

Brunauer-Emmett-Teller (BET) measurements were used to investigate any major differences in particle specific surface area, as it is a major contributor in improving pseudocapacitive charge storage. The results showed only relatively small differences in specific surface areas for the samples. The specific surface areas of $\mathrm{MoO}_{2}, \quad \mathrm{Mo}_{0.67} \mathrm{~V}_{0.33} \mathrm{O}_{2}, \quad \mathrm{Mo}_{0.5} \mathrm{~V}_{0.5} \mathrm{O}_{2}, \quad \mathrm{Mo}_{0.33} \mathrm{~V}_{0.67} \mathrm{O}_{2}, \quad \mathrm{Mo}_{0.1} \mathrm{~V}_{0.9} \mathrm{O}_{2}$, $\mathrm{Mo}_{0.05} \mathrm{~V}_{0.95} \mathrm{O}_{2}$ and $\mathrm{VO}_{2}$ were $20,31,43,34,36,33$ and $40 \mathrm{~m}^{2} \mathrm{~g}^{-1}$. These values were comparable to those previously reported for mixed molybdenum-vanadium oxides [22].

X-ray absorption spectroscopy (XAS) of the V K-edge (Fig. 3a) and Mo K-edge (Fig. $3 \mathrm{~b}$ ) was employed to further investigate the bulk oxidation state chemistry of the $\mathrm{Mo}_{\mathrm{x}} \mathrm{V}_{1-\mathrm{x}} \mathrm{O}_{2}$ samples. In these spectra, two contributions of interest were observed; the lower energy peak (pre-edge) can be ascribed to the $1 \mathrm{~s}$ to $3 d$ electronic transition and the higher energy contribution (rising edge) is due to $1 \mathrm{~s}$ to $4 p+n$ transitions. In most cases, the $\mathrm{V}$ rising edge shifted to higher energy with increasing amounts of vanadium, indicating a shift to higher effective oxidation state [52,53]. $\mathrm{Mo}_{0.5} \mathrm{~V}_{0.5} \mathrm{O}_{2}$ does not follow the trend, indicating a complex electronic relationship sensitive to the metals composition between $\mathrm{Mo}_{0.67} \mathrm{~V}_{0.33} \mathrm{O}_{2}$ and $\mathrm{Mo}_{0.33} \mathrm{~V}_{0.67} \mathrm{O}_{2}$. In contrast, there is no significant change in the rising edge of the Mo K-edge and, therefore, cannot be used to describe the changes in oxidation state. However, as the concentration of Mo increases, there is a decrease in intensity of the preedge feature indicative of $\mathrm{Mo}(\mathrm{VI})$ and usually associated with tetrahedralization but also present in *distorted) octahedral geometries [54,55]. It is therefore suggested that Mo initially populates the surface where it is easily oxidised to $\mathrm{Mo}(\mathrm{IV})$ and then infiltrates the bulk at higher concentrations where it adopts Mo(IV), protected from oxidation.

The Fourier transforms (FT) of the V K-edge data in Fig. 3c demonstrated similar local environments around $V$ atoms for all samples, which were not in good agreement with the $M_{1}$ phase. Peaks associated with the $\mathrm{V}-\mathrm{O}$ coordination of the $\mathrm{M}_{1}$ phase would be expected at ca. 1.35 and $1.75 \AA$, whilst $\mathrm{V}-\mathrm{V}$ shells correspond to peaks at ca. 2.15 and $2.95 \AA$ [56]. For the samples with no molybdenum or a low concentration $\left(\mathrm{Mo}_{0.1} \mathrm{~V}_{0.9} \mathrm{O}_{2}, \mathrm{Mo}_{0.05} \mathrm{~V}_{0.95} \mathrm{O}_{2}\right.$ and $\mathrm{VO}_{2}$ ), there was a peak at ca. $2.95 \AA$ which might be correlated to the $\mathrm{V}-\mathrm{V}$ shells. However, for the samples with higher concentrations of molybdenum $\left(\mathrm{Mo}_{0.67} \mathrm{~V}_{0.33} \mathrm{O}_{2}, \mathrm{Mo}_{0.5} \mathrm{~V}_{0.5} \mathrm{O}_{2}, \mathrm{Mo}_{0.33} \mathrm{~V}_{0.67} \mathrm{O}_{2}\right)$, there was a peak at ca. $3.3 \AA$, which potentially indicated changes in the $\mathrm{V}-\mathrm{V}$ distances for these samples. The FT of the Mo K-edge XAS was plotted in Fig. 3d. The plot for $\mathrm{MoO}_{2}$ showed the features expected from monoclinic $\mathrm{M}_{1}\left(\mathrm{MoO}_{2}\right)$ with a major peak at ca. $1.4 \AA$ corresponding to the Mo-O coordination and features at ca. 2.0 and $3.2 \AA$ associated with Mo-Mo coordination [57]. For mixed molybdenum/vanadium oxides with a high concentration of molybdenum $\left(\mathrm{Mo}_{0.67} \mathrm{~V}_{0.33} \mathrm{O}_{2}, \mathrm{Mo}_{0.5} \mathrm{~V}_{0.5} \mathrm{O}_{2}, \mathrm{Mo}_{0.33} \mathrm{~V}_{0.67} \mathrm{O}_{2}\right)$ the FTs were like that of monoclinic $\left(\mathrm{M}_{1}\right) \mathrm{MoO}_{2}$. However, the peak at ca. $3.2 \AA$ was suppressed significantly, which possibly indicated less Mo-Mo coordination [58]. The FTs for the mixed oxides with a low concentration of molybdenum $\left(\mathrm{Mo}_{0.1} \mathrm{~V}_{0.9} \mathrm{O}_{2}, \mathrm{Mo}_{0.05} \mathrm{~V}_{0.95} \mathrm{O}_{2}\right)$ were significantly different to the other samples (and especially $\mathrm{M}_{1}$ $\mathrm{MoO}_{2}$ ), indicating a different local environment. This could indicate that the molybdenum in these samples was coordinated with the $\mathrm{VO}_{2}$, whereas it was not for the samples with higher molybdenum concentrations.

Transmission electron microscopy (TEM) showed agglomerates of nanoparticles with a particle size below $50 \mathrm{~nm}$ for all samples. For $\mathrm{Mo}_{0.67} \mathrm{~V}_{0.33} \mathrm{O}_{2}$ and $\mathrm{Mo}_{0.33} \mathrm{~V}_{0.67} \mathrm{O}_{2}$, agglomerates were composed of nanoparticles of variable size and morphology (see Fig. 4a and b, and Fig. $4 \mathrm{e}$ and $\mathrm{f}$, respectively); $\mathrm{Mo}_{0.5} \mathrm{~V}_{0.5} \mathrm{O}_{2}$ showed a single, smaller particle size (ca. $5 \mathrm{~nm}$ in diameter) and narrower morphology distribution (see Fig. $4 \mathrm{c}$ and d), in good agreement with the BET analysis. The smaller particle size observed for $\mathrm{Mo}_{0.5} \mathrm{~V}_{0.5} \mathrm{O}_{2}$ is likely due to a reaction environment that is 

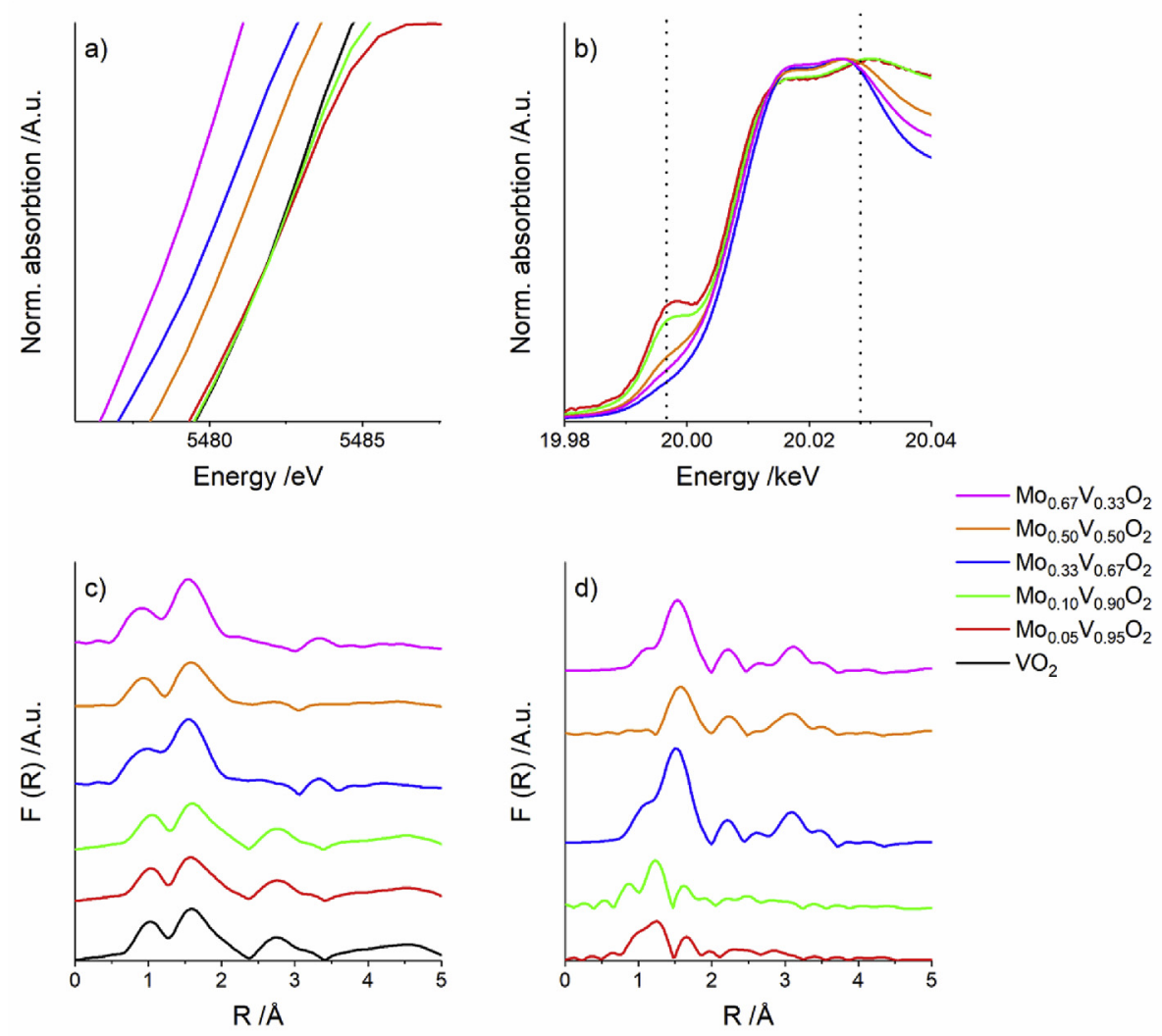

Fig. 3. a) V K-edge and b) Mo K-edge XAS spectra for the mixed Mo/V oxides samples. Fourier transforms for the c) V K-edge and d) Mo K-edge data.

favourable for limiting particle growth, when compared to $\mathrm{Mo}_{0.67} \mathrm{~V}_{0.33} \mathrm{O}_{2}$ and $\mathrm{Mo}_{0.33} \mathrm{~V}_{0.67} \mathrm{O}_{2}$, due to differences in reactant concentration. Energy dispersive X-ray spectroscopy (EDX) mapping showed an even distribution of molybdenum and vanadium throughout all samples (see Fig. S4), supporting solid solutions of monoclinic $\mathrm{Mo}_{\mathrm{n}} \mathrm{V}_{\mathrm{n}-1} \mathrm{O}_{2+\mathrm{x}}$ for all samples. Like the atomic quantities as determined from XPS, atomic concentrations determined via EDX were in good agreement with nominal values during synthesis (see Fig. S4). However, both the oxidation states of the metals and the elemental analysis indicated that the concentration of oxygen was above its nominal value of 2 , which could, however, also be a result of oxygen adsorption onto the carbon tape. The samples are referred to by their nominal concentrations for legibility.

\subsection{Electrochemical characterization}

All materials were initially investigated via cyclic voltammetry $(\mathrm{CV})$ at various scan rates in the potential window 3.00 to $0.05 \mathrm{~V}$ vs. $\mathrm{Li} / \mathrm{Li}^{+}$. The first two cycles of $\mathrm{Mo}_{0.05} \mathrm{~V}_{0.95} \mathrm{O}_{2}$ and $\mathrm{VO}_{2}$ showed similar profiles, with reversible peaks at ca. $2.5 \mathrm{~V}$ vs. $\mathrm{Li} / \mathrm{Li}^{+}$, whereas the reversible peak for $\mathrm{Mo}_{0.1} \mathrm{~V}_{0.9} \mathrm{O}_{2}$ was shifted to lower potentials vs. $\mathrm{Li} / \mathrm{Li}^{+}$(see Fig. 5a). The changes for the first two cyclic voltammograms for $\mathrm{Mo}_{0.5} \mathrm{~V}_{0.5} \mathrm{O}_{2}$ and $\mathrm{Mo}_{0.33} \mathrm{~V}_{0.67} \mathrm{O}_{2}$ compared to $\mathrm{VO}_{2}$ were significant (see Fig. 5b). Especially for $\mathrm{Mo}_{0.5} \mathrm{~V}_{0.5} \mathrm{O}_{2}$, at least three distinct reversible peaks could be observed from the cyclic voltammograms. For $\mathrm{Mo}_{0.67} \mathrm{~V}_{0.33} \mathrm{O}_{2}$, the differences between first and second cycles were most significant and indicated large irreversible capacity losses due to irreversible conversion reactions.

Scan rate tests revealed more significant differences between pure $\mathrm{VO}_{2}$ and samples containing higher concentrations of molybdenum. At a scan rate of $0.1 \mathrm{mV} \mathrm{s}^{-1}$, the peaks for $\mathrm{Mo}_{0.67} \mathrm{~V}_{0.33} \mathrm{O}_{2}$,
$\mathrm{Mo}_{0.5} \mathrm{~V}_{0.5} \mathrm{O}_{2}$, and $\mathrm{Mo}_{0.33} \mathrm{~V}_{0.67} \mathrm{O}_{2}$ were shifted to lower potentials vs. $\mathrm{Li} / \mathrm{Li}^{+}$, and additional peaks appeared for $\mathrm{Mo}_{0.5} \mathrm{~V}_{0.5} \mathrm{O}_{2}$, and $\mathrm{Mo}_{0.33} \mathrm{~V}_{0.67} \mathrm{O}_{2}$, potentially owing to the presence of molybdenum (in various valence states) and vanadium in valence states other than V(IV) (see Fig. 5c). At high scan rates, cyclic voltammograms broadened significantly, indicative of an increase in pseudocapacitive charge storage contributions [59]. Whilst $\mathrm{VO}_{2}$ showed broadened peaks in the range $0.05-1.00 \mathrm{~V} \mathrm{vs}$. $\mathrm{Li} / \mathrm{Li}^{+}$, the profiles for $\mathrm{Mo}_{0.5} \mathrm{~V}_{0.5} \mathrm{O}_{2}$ and $\mathrm{Mo}_{0.33} \mathrm{~V}_{0.67} \mathrm{O}_{2}$ were broadened over the whole potential range (see Fig. $5 \mathrm{~d}$ as well as Fig. S5).

The contributions of pseudocapacitive charge to the total charge storage, was determined via a method first used by Augustyn et al. (see Equation $S(1)$, Supplemental) [60]. The charge storage at a theoretical, unlimited rate was found to be highest for $\mathrm{Mo}_{0.5} \mathrm{~V}_{0.5} \mathrm{O}_{2}$ and $\mathrm{Mo}_{0.33} \mathrm{~V}_{0.67} \mathrm{O}_{2}$ (see Fig. 6a). The pseudocapacitive charge stored at a theoretical, infinitely fast scan rate was 468, 357, 263, 712, 825 and $50 \mathrm{Cg}^{-1}$ for $\mathrm{VO}_{2}, \mathrm{Mo}_{0.05} \mathrm{~V}_{0.95} \mathrm{O}_{2}, \mathrm{Mo}_{0.1} \mathrm{~V}_{0.9} \mathrm{O}_{2}, \mathrm{Mo}_{0.33} \mathrm{~V}_{0.67} \mathrm{O}_{2}$, $\mathrm{Mo}_{0.5} \mathrm{~V}_{0.5} \mathrm{O}_{2}$, and $\mathrm{Mo}_{0.67} \mathrm{~V}_{0.33} \mathrm{O}_{2}$, respectively. The pseudocapacitive charge storage contributions at $0.1 \mathrm{mV} \mathrm{s}^{-1}$ for $\mathrm{VO}_{2}, \mathrm{Mo}_{0.05} \mathrm{~V}_{0.95} \mathrm{O}_{2}$, and $\mathrm{Mo}_{0.1} \mathrm{~V}_{0.9} \mathrm{O}_{2}$ were 42, 40, and $31 \%$, respectively. For $\mathrm{Mo}_{0.33} \mathrm{~V}_{0.67} \mathrm{O}_{2}, \mathrm{Mo}_{0.5} \mathrm{~V}_{0.5} \mathrm{O}_{2}$, and $\mathrm{Mo}_{0.67} \mathrm{~V}_{0.33} \mathrm{O}_{2}$, these contributions were 43,50 , and $7 \%$, respectively (see Fig. $6 \mathrm{~b}$ ). At increased scan rates of $10.0 \mathrm{mV} \mathrm{s}^{-1}$, the pseudocapacitive charge storage contributions increased significantly to $85,83,81,89,92$, and $45 \%$ for $\mathrm{VO}_{2}$, $\mathrm{Mo}_{0.05} \mathrm{~V}_{0.95} \mathrm{O}_{2}, \quad \mathrm{Mo}_{0.1} \mathrm{~V}_{0.9} \mathrm{O}_{2}, \quad \mathrm{Mo}_{0.33} \mathrm{~V}_{0.67} \mathrm{O}_{2}, \quad \mathrm{Mo}_{0.5} \mathrm{~V}_{0.5} \mathrm{O}_{2}$, and $\mathrm{Mo}_{0.67} \mathrm{~V}_{0.33} \mathrm{O}_{2}$, respectively (see Fig. 7).

A simplified Cottrell equation (see Equation S(4), Supplemental) was used to determine a range of $b$-values from the slopes of plots for Equation (1) (see Fig. 6c) in a range of scan rates of $0.1-5 \mathrm{mV} \mathrm{s}^{-1}$ : 

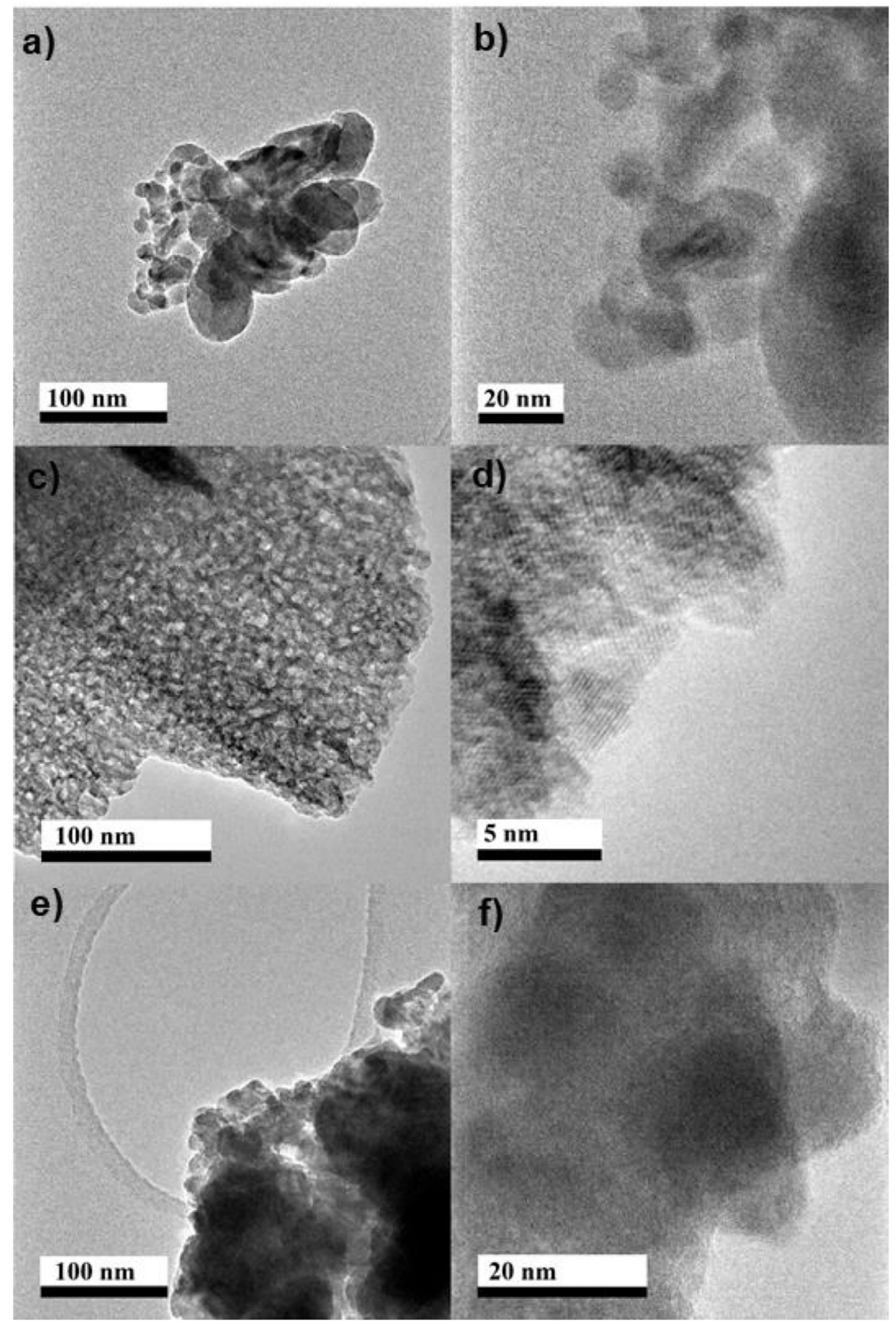

f)

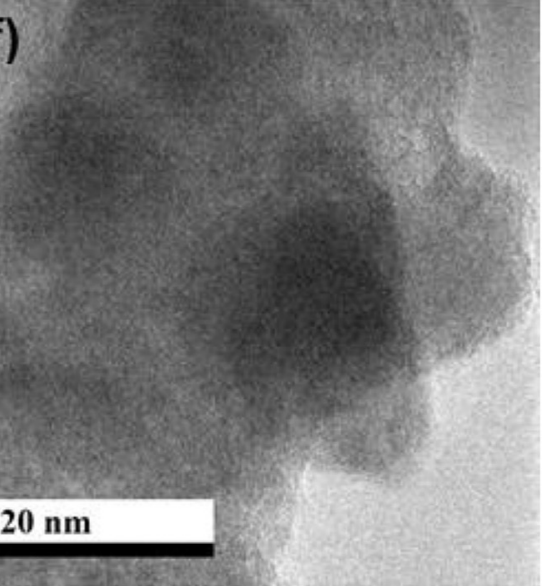

Fig. 4. Transmission electron microgramphs for $\left.\mathrm{a}+\mathrm{b}) \mathrm{Mo}_{0.67} \mathrm{~V}_{0.33} \mathrm{O}_{2}, \mathrm{c}+\mathrm{d}\right) \mathrm{Mo}_{0.5} \mathrm{~V}_{0.5} \mathrm{O}_{2}$, and e $+\mathrm{f}$ ) $\mathrm{Mo}_{0.33} \mathrm{~V}_{0.67} \mathrm{O}_{2}$.

$i=a \nu^{b}$

In this, $i$ is current, $a$ is a constant (a combination of constants in the Cottrell equation), and $b$ is an adjustable parameter. Because the current due to capacitive processes scales linearly with the scan rate $(b=1.0)$ and the current due to diffusion-limited processes scales linearly with the square root of the scan rate $(b=0.5)$, values for $b$ closer to 0.5 indicated mostly diffusion-limited charge storage, whereas values for $b$ closer to 1.0 indicated mostly capacitive charge storage. As can be seen from Fig. S6 (Supplementary), the charge storage mechanism for $\mathrm{Mo}_{0.5} \mathrm{~V}_{0.5} \mathrm{O}_{2}$ was mostly capacitive over most of the potential window ( $b$ values mostly $>0.85$ ). Only at potentials near the lower potential limit $\left(>0.5 \mathrm{~V}\right.$ vs. $\left.\mathrm{Li} / \mathrm{Li}^{+}\right) \mathrm{did} b$ values approach ca. 0.70 , which indicated mostly diffusion-limited charge storage, but still accompanied by significant capacitive charge storage.

To further investigate the charge storage in $\mathrm{Mo}_{0.5} \mathrm{~V}_{0.5} \mathrm{O}_{2}$, the power law relationships for capacitive and diffusion-limited currents (see Eq. $S(8)$, Supplemental) were used to plot linear graphs based on Equation (2) to obtain the two parameters $a_{1}$ and $a_{2}$ :

$\frac{i(V)}{\nu^{0.5}}=a_{1} \nu^{0.5}+a_{2}$ 

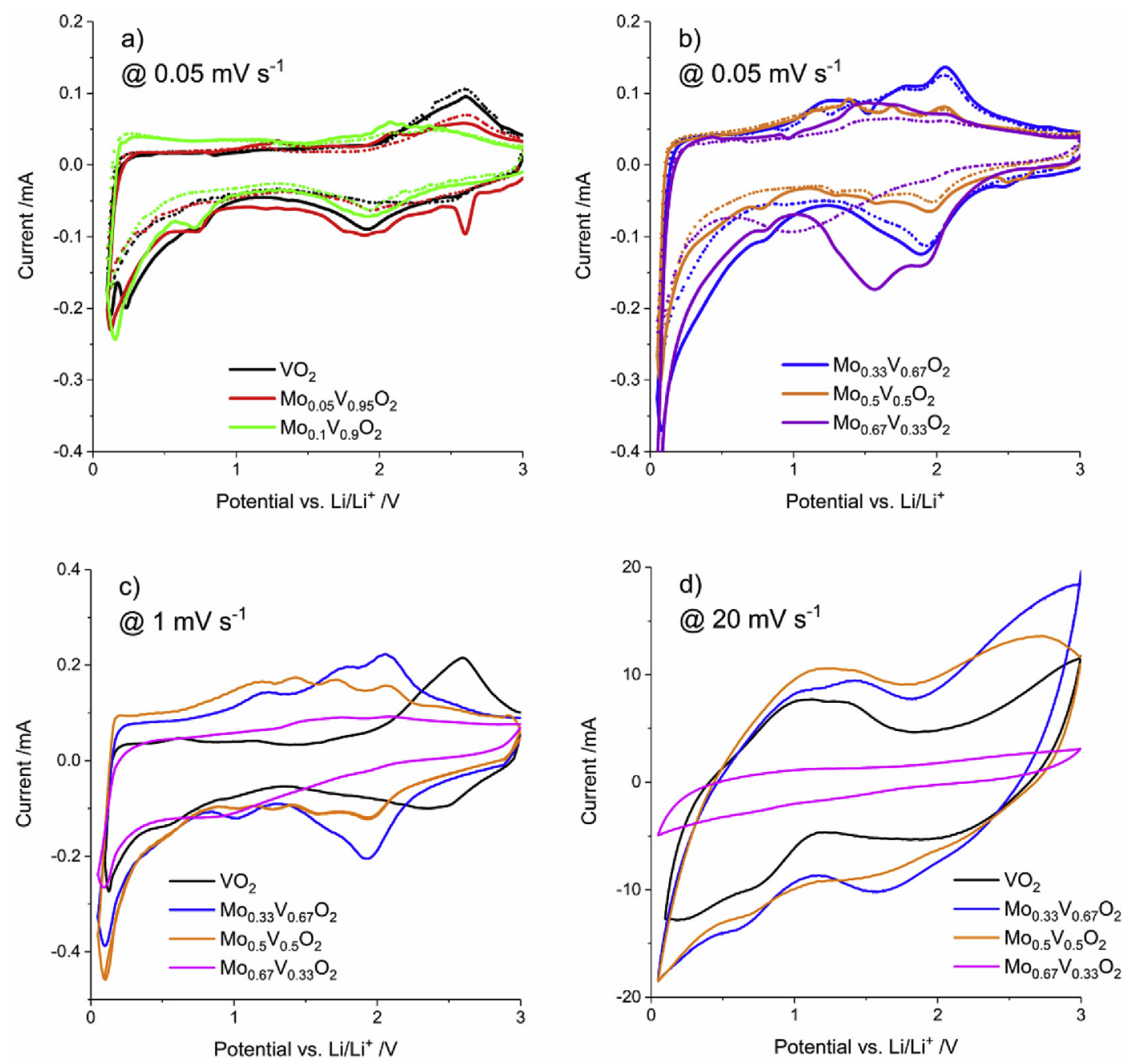

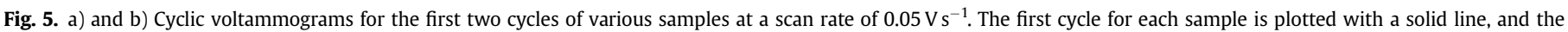
second cycle with a dashed line. Cyclic voltammograms for $\mathrm{Mo}_{0.67} \mathrm{~V}_{0.33} \mathrm{O}_{2}, \mathrm{Mo}_{0.5} \mathrm{~V}_{0.5} \mathrm{O}_{2}, \mathrm{Mo}_{0.33} \mathrm{~V}_{0.67} \mathrm{O}_{2}$, and $\mathrm{VO}_{2}$ at $\mathrm{scan}$ rates of c) 0.1 and d) $20 \mathrm{mV} \mathrm{s}^{-1}$.

These parameters could then be used to calculated contributions to the current from capacitive and diffusion-limited processes at different potentials (see Fig. S7, Supplemental). The pseudocapacitive contributions were plotted in Fig. $6 \mathrm{~d}$ along with the cyclic voltammogram for $\mathrm{Mo}_{0.5} \mathrm{~V}_{0.5} \mathrm{O}_{2}$ at a scan rate of $1 \mathrm{mV} \mathrm{s}^{-1}$. The pseudocapacitive contributions, calculated from the ratio of the charge storage of both cyclic voltammograms, were ca. $77 \%$.

The excellent charge storage at high rates was confirmed by results from galvanostatic testing at various specific currents. Whilst the performance decreased significantly with increasing specific currents for samples with a low concentration of molybdenum (e.g. $\mathrm{Mo}_{0.05} \mathrm{~V}_{0.95} \mathrm{O}_{2}$ and $\mathrm{Mo}_{0.1} \mathrm{~V}_{0.9} \mathrm{O}_{2}$ showed specific capacities of 300 and 75 , and 230 and $45 \mathrm{mAh} \mathrm{g}^{-1}$ at 0.1 and $5 \mathrm{Ag}^{-1}$, respectively), it increased for samples with a higher molybdenum concentration. $\mathrm{Mo}_{0.33} \mathrm{~V}_{0.67} \mathrm{O}_{2}$ and $\mathrm{Mo}_{0.5} \mathrm{~V}_{0.5} \mathrm{O}_{2}$ showed excellent specific capacities of 450 and $220 \mathrm{mAh} \mathrm{g}^{-1}$ and 540 and $255 \mathrm{mAh}$ $\mathrm{g}^{-1}$, respectively, at specific currents of 0.1 and $5 \mathrm{~A} \mathrm{~g}^{-1}$, respectively. For $\mathrm{Mo}_{0.5} \mathrm{~V}_{0.5} \mathrm{O}_{2}$, this meant that a specific capacity of $200 \mathrm{mAh} \mathrm{g}^{-1}$ could be stored or discharged within $72 \mathrm{~s}$. This performance was significantly better than $\mathrm{VO}_{2}$ synthesised via CHFS, which only showed a specific capacity of $95 \mathrm{mAh} \mathrm{g}-1$ at $10 \mathrm{Ag}^{-1}$ [11]. The performance was comparable to lithiated mixed vanadiummolybdenum oxide $\mathrm{LiVMoO}_{6}$ which showed a capacity of 285 $\mathrm{mAh} \mathrm{g}^{-1}$ at a current rate of $5 \mathrm{Ag}^{-1}$ [21]. For even higher molybdenum concentrations, the electrochemical performance was reduced. $\mathrm{Mo}_{0.67} \mathrm{~V}_{0.33} \mathrm{O}_{2}$ showed significant losses in capacity after the first cycle and very low Coulombic efficiencies, indicative of large irreversible side reactions commonly observed for $\mathrm{MoO}_{2}$ electrodes [12,20]. The Coulombic efficiencies of 63 and $65 \%$ for $\mathrm{Mo}_{0.33} \mathrm{~V}_{0.67} \mathrm{O}_{2}$ and $\mathrm{Mo}_{0.5} \mathrm{~V}_{0.5} \mathrm{O}_{2}$, respectively, during the first cycle could be explained by the formation of solid electrolyte interphase (SEI) and some irreversible side reactions.

As can be seen from Fig. 8a, the charging and discharging profiles for $\mathrm{Mo}_{0.5} \mathrm{~V}_{0.5} \mathrm{O}_{2}$ showed no significant intercalation plateaus. Hence, few two-phase intercalation reactions were expected. Plotting the differential capacity for the third cycle at $0.1 \mathrm{Ag}^{-1}$, revealed three very minor peaks in the potential range $1.0-2.5 \mathrm{~V}$ vs. $\mathrm{Li} / \mathrm{Li}^{+}$(see Fig. S8, Supplemental). Because of the small size of the nanoparticles, the materials seemed to show no miscibility gap for $\mathrm{Li}^{+}$accommodation. Similar profiles have been described previously for a range of nanoparticles such as $\mathrm{TiO}_{2}$ [61,62], $\mathrm{LiMn}_{2} \mathrm{O}_{4}$ [63], and $\mathrm{V}_{2} \mathrm{O}_{5}$ [48]. This could be explained by the higher number of surface sites in a range of energies available for fast Faradaic reactions, resulting in sloped charge/discharge profile [59]. This behavior did not change significantly at higher specific currents (see Fig. 8b), although overpotentials did increase (as would be expected). Another interesting feature was the increase in specific capacity with cycle number at $0.1 \mathrm{Ag}^{-1}$; a similar behaviour has 

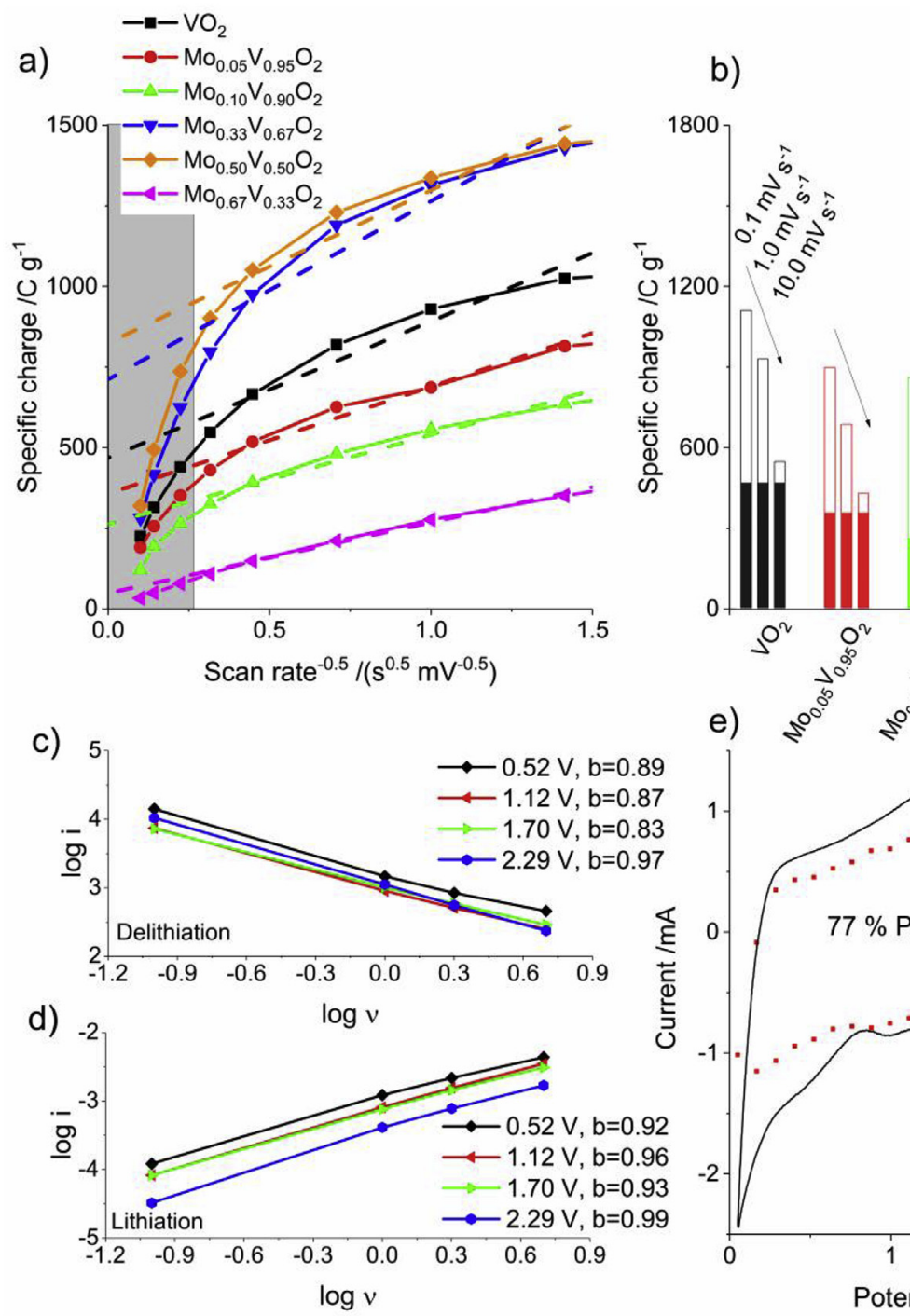

e)
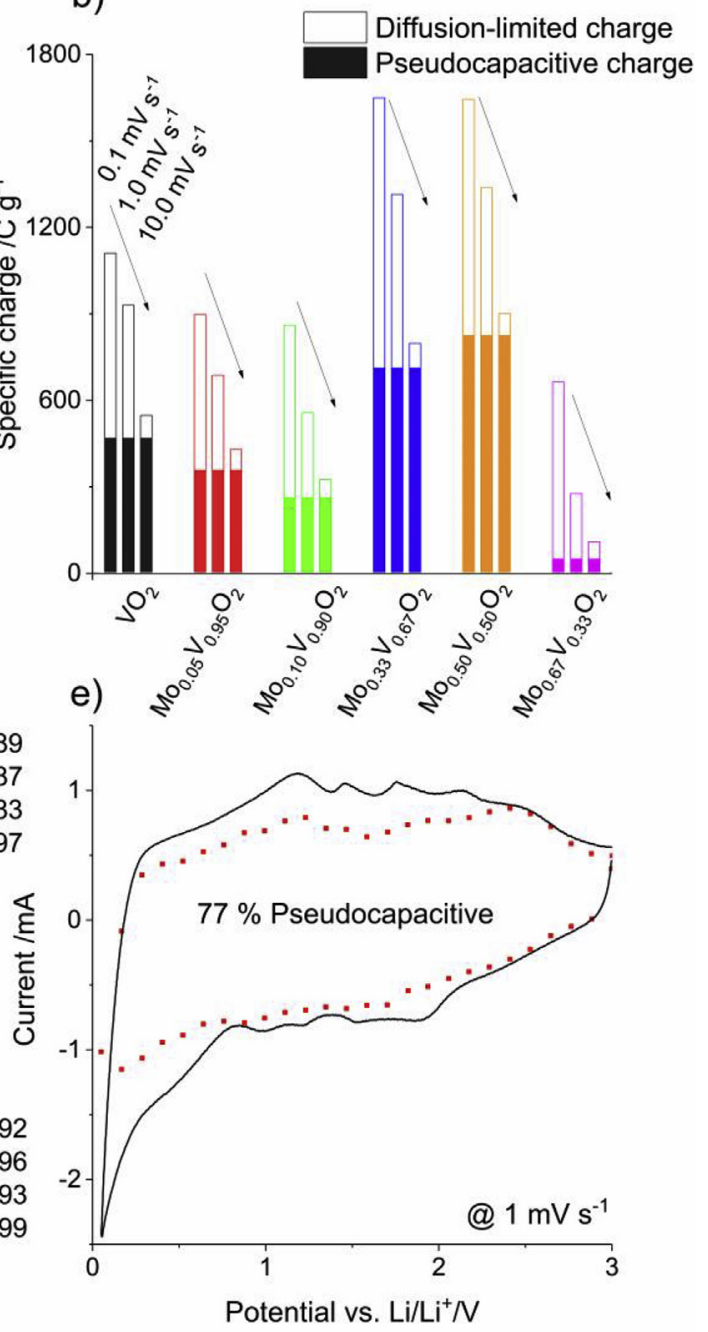

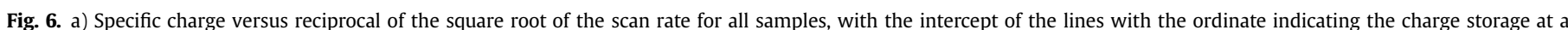

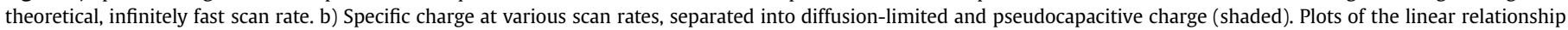

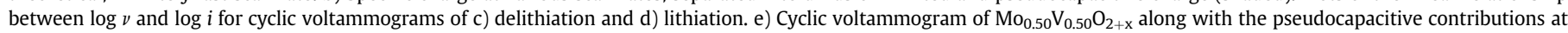
this scan rate at different potentials.

been observed in porous metal oxide electrodes and were ascribed to an increase in lithium diffusion kinetics, increased access of electrolyte into the porous electrode upon cycling, and the gradual activation process of conversion reactions for both $\mathrm{MoO}_{\mathrm{x}}$ and $\mathrm{VO}_{\mathrm{x}}$ [64-66]. Additionally, the formation of Mo and V nanoparticles during cycling and their role in the lithium oxide back reaction ( $\mathrm{Li}_{2} \mathrm{O}$ to $\mathrm{Li}$ ) might have led to the increased capacities upon cycling at the lower current rates [22].

$\mathrm{Mo}_{0.5} \mathrm{~V}_{0.5} \mathrm{O}_{2}$ also showed excellent cycling stability, with a specific capacity of $483 \mathrm{mAh} \mathrm{g}^{-1}$ after 150 cycles at $1.0 \mathrm{Ag}^{-1}$, a capacity retention of $84 \%$ compared to the specific capacity in the first cycle of $574 \mathrm{mAh} \mathrm{g}^{-1}$ (see Fig. $8 \mathrm{c}$ and d). In contrast to the cycling at low rates of $0.1 \mathrm{Ag}^{-1}$, no increase in capacity was observed, possibly because the ten-times higher specific current did not allow for the gradual activation processes described above $[64,67]$. Interestingly, the first cycle Coulombic efficiency at $1.0 \mathrm{~A} \mathrm{~g}^{-1}$ was significantly higher than at lower specific currents of $0.1 \mathrm{Ag}^{-1}$ (94 and 65\%, respectively), which indicated that first cycle SEI formation was relatively smaller. As shown previously in Fig. 8a, the charge/ discharge curves showed no discernible plateaus (see Fig. 8d). The performance was significantly more stable than that previously reported for $\mathrm{MoO}_{2}$-graphene materials, which showed a decrease to $55 \%$ of initial specific capacity to $445 \mathrm{mAh} \mathrm{g}^{-1}$ after 100 cycles at a specific current of $0.5 \mathrm{Ag}^{-1}$ [24], and for $\mathrm{VO}_{2}$, which showed a decrease in specific capacity from 460 to $200 \mathrm{mAh} \mathrm{g}^{-1}$ after 200 cycles at $0.1 \mathrm{~mA}$ [28].

Electrochemical impedance spectroscopy was carried out to gain further understanding of the properties of $\mathrm{Mo}_{0.33} \mathrm{~V}_{0.67} \mathrm{O}_{2}$ and $\mathrm{Mo}_{0.5} \mathrm{~V}_{0.5} \mathrm{O}_{2}$ and to compare them to samples with higher or lower molybdenum content. It became apparent from the impedance spectra that SEI film resistance and charge-transfer resistance of $\mathrm{Mo}_{0.33} \mathrm{~V}_{0.67} \mathrm{O}_{2}$ and $\mathrm{Mo}_{0.5} \mathrm{~V}_{0.5} \mathrm{O}_{2}$ were significantly lower than those for $\mathrm{Mo}_{0.67} \mathrm{~V}_{0.33} \mathrm{O}_{2}$ and $\mathrm{Mo}_{0.1} \mathrm{~V}_{0.9} \mathrm{O}_{2}$ (see Fig. S9). Further study of $\mathrm{Mo}_{0.5} \mathrm{~V}_{0.5} \mathrm{O}_{2}$ via staircase potentio electrochemical impedance spectroscopy (SPEIS, see Fig. S10) revealed that after cycling for 50 cycles at a specific current of $0.5 \mathrm{Ag}^{-1}$, charge transfer resistance and solid electrolyte interphase resistance at potentials in the range $0.05-2.00 \mathrm{~V}$ vs. $\mathrm{Li} / \mathrm{Li}^{+}$during lithiation were significantly lower than during the first cycle or before cycling, indicating pseudocapacitive charge storage. 

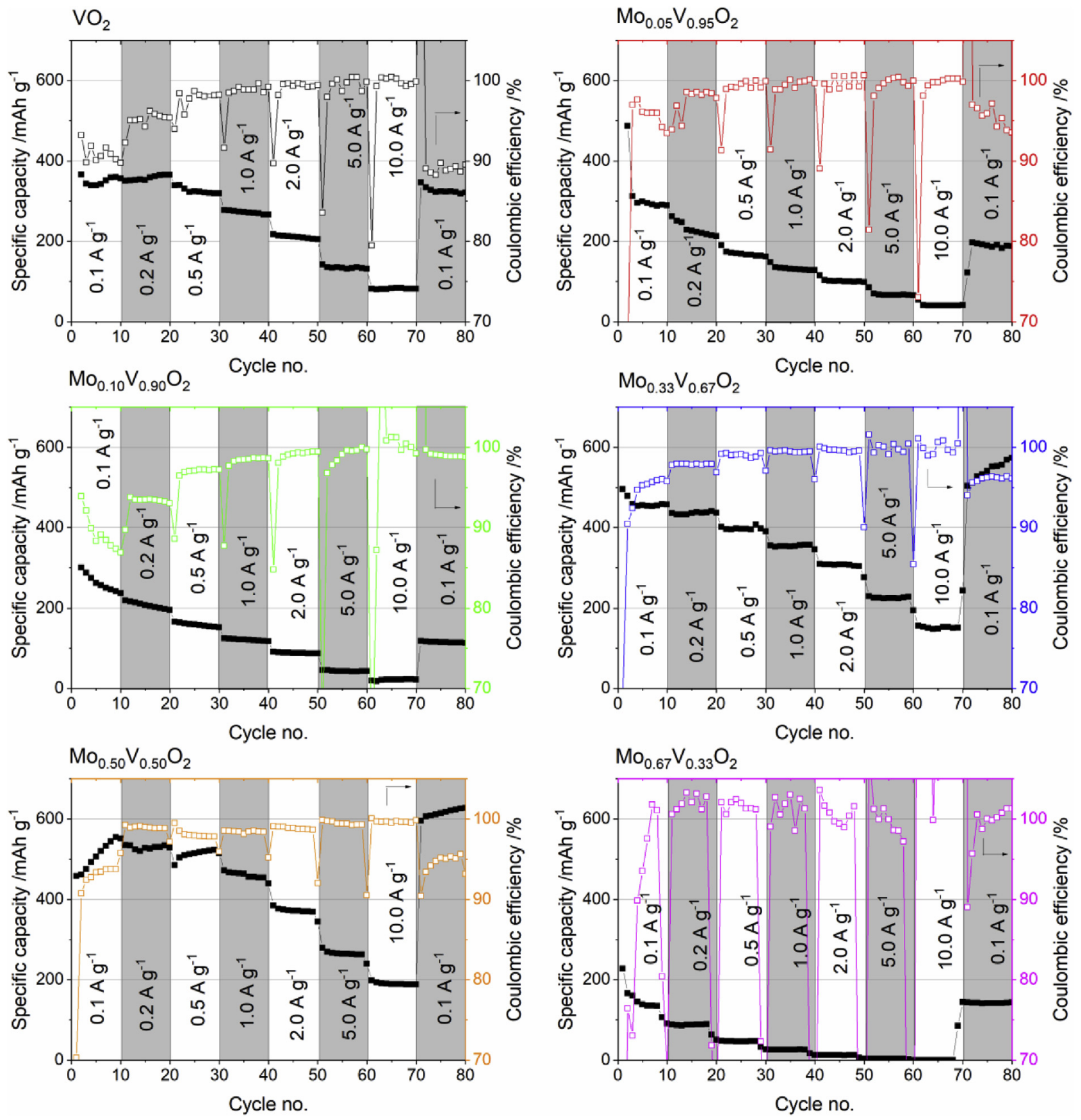

Fig. 7. Galvanostatic measurements at various specific currents for all samples with Coulombic efficiencies.

Galvanostatic Intermittent Titration Technique (GITT) was used (see Figs. S11a-c) to determine the diffusion kinetics of $\mathrm{Mo}_{0.5} \mathrm{~V}_{0.5} \mathrm{O}_{2+\mathrm{x}}$. It showed that the diffusion coefficients were in the region of $10^{-11} \mathrm{~cm}^{2} \mathrm{~s}^{-1}$ over most of the active potential window (see Fig. S11d). During the lithiation, there is a drop of the diffusion coefficient at ca. $1.5 \mathrm{~V}$ vs. $\mathrm{Li} / \mathrm{Li}^{+}$and the diffusion coefficient falls significantly at low potentials. The drop at the middle of the potential window could indicate the occurrence of phase transitions which coincide with the peaks in the CVs and the differential capacity. Similar correlations have previously been observed for other electrode materials [68].

The Li-ion diffusion coefficient for $\mathrm{Mo}_{0.5} \mathrm{~V}_{0.5} \mathrm{O}_{2+\mathrm{x}}$ was also determined from Electrochemical Impedance Spectroscopy (EIS) measurements. After cycling for 20 cycles, the Warburg impedance was determined from the diffusion-limited low frequency region of the Nyquist plot (see Fig. $\mathrm{S} 12, \mathrm{OCV}=2.1 \mathrm{~V}$ vs. $\mathrm{Li} / \mathrm{Li}^{+}$). The Warburg impedance was determined from the slope of the plot of the real impedance versus the reciprocal square root of the angular frequency (see inset of Fig. S12). The slope of the potential change with the number of Li-ions in the material was determined to be near unity throughout the galvanostatic charging/discharging. The diffusion coefficient was calculated using Eq. (3):

$D_{L i^{+}}=0.5\left[\left(\frac{V_{M}}{A F \sigma_{\text {WARBURG }}}\right) \frac{\delta E}{\delta x}\right]$

The diffusion coefficient is calculated using the molar volume $\left(V_{M}\right)$, the geometric area of the electrode $(A)$, Faraday's constant $(F)$ and the slope of the galvanostatic charge/discharge curve $\left(\frac{\delta E}{\delta x}\right)$. The Warburg impedance was $29.1 \Omega \mathrm{s}^{-0.5}$ and the Li-ion diffusion coefficient was ca. $10^{-11} \mathrm{~cm}^{2} \mathrm{~s}^{-1}$. This was in good agreement with the diffusion coefficients determined from GITT. 
a)

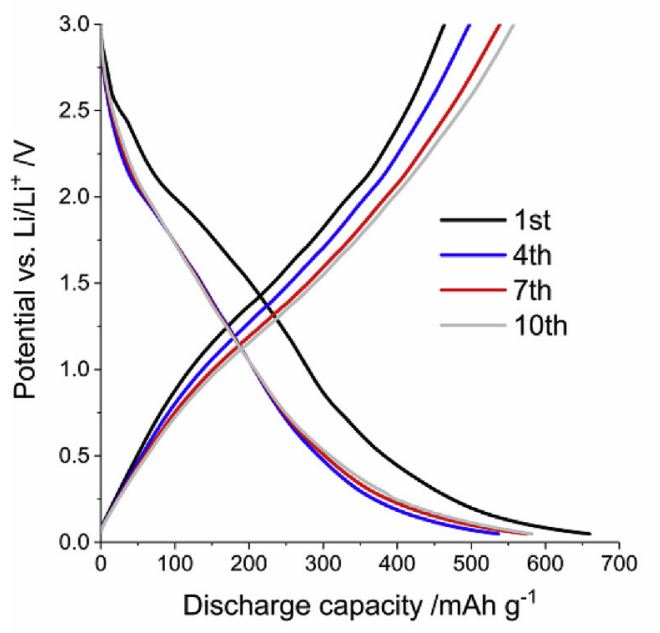

c)

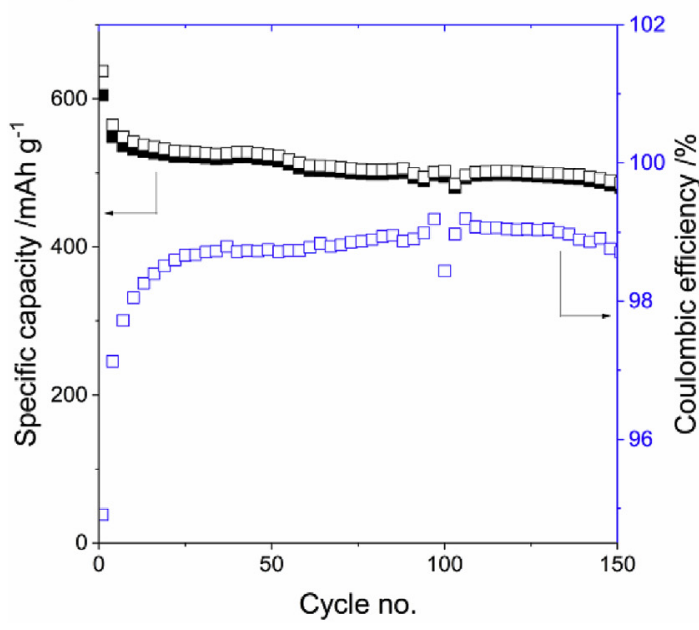

b)
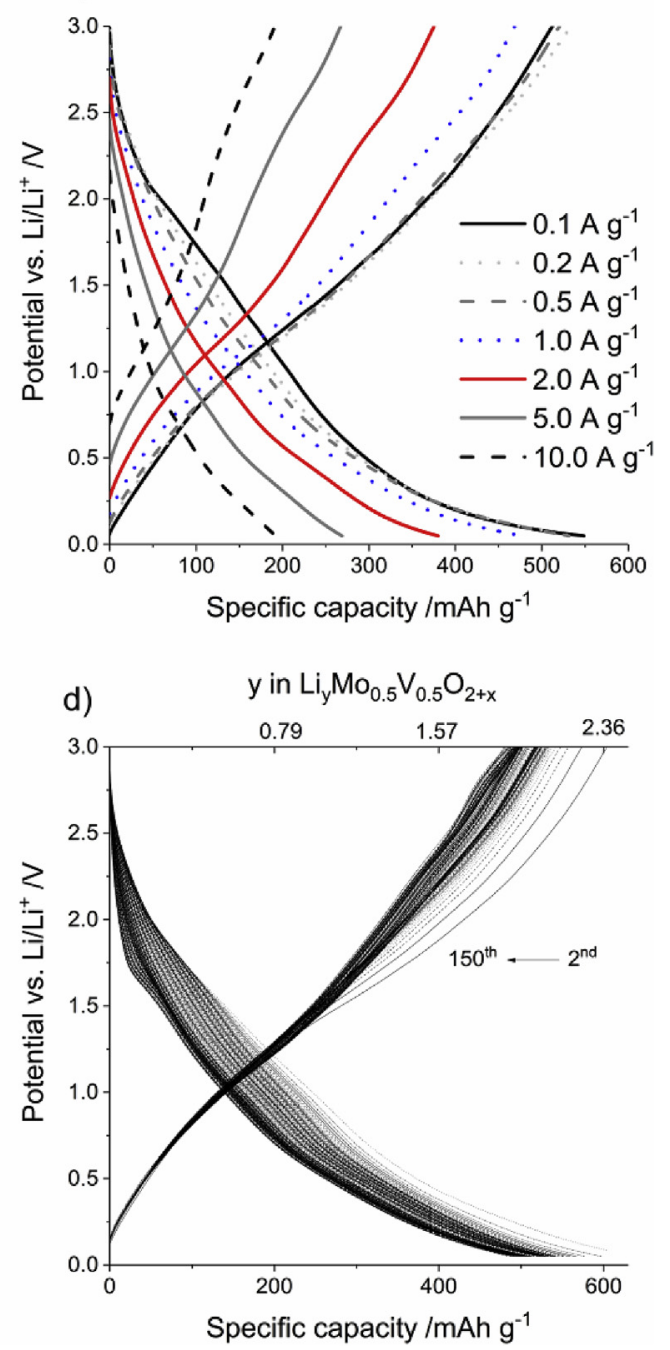

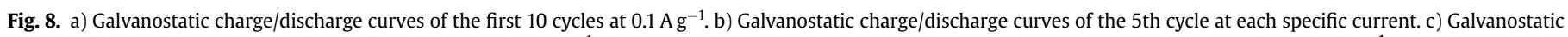
cycling stability test for $\mathrm{Mo}_{0.5} \mathrm{~V}_{0.5} \mathrm{O}_{2}$ at a specific current of $1 \mathrm{Ag}^{-1}$. d) Galvanostatic charge/discharge curves for $\mathrm{Mo}_{0.5} \mathrm{~V}_{0.5} \mathrm{O}_{2}$ at a specific current of $1.0 \mathrm{Ag} \mathrm{g}^{-1}$.

The $\mathrm{Mo}_{0.5} \mathrm{~V}_{0.5} \mathrm{O}_{2}$ electrodes were studied in more detail via XPS and XRD before cycling, after being fully lithiated at a specific current of $0.1 \mathrm{Ag}^{-1}$, and after cycling for 50 cycles at a specific current of $0.1 \mathrm{~A} \mathrm{~g}^{-1}$ in a fully delithiated state. As expected, the XPS peaks for both Mo $3 d$ and $V 2 p$ shifted to lower binding energies, indicating the presence of lower-valence state metals in the lithiated electrode after the first lithiation (see Fig. S13). However, the electrode that was "fully" delithiated (after 50 cycles) showed even larger shifts to lower binding energies; hence, the metal ions in the electrode were reduced to even lower oxidation states. This could be explained by a gradual activation process, which has been observed and reported elsewhere [64,65]. Interestingly, the XRD patterns of the lithiated electrode showed no obvious shifts in peak positions after the first lithiation, which would have indicated changes in lattice parameters due to lithium intercalation (see Fig. S14). Furthermore, there was no indication of crystalline parts of SEI after the first lithiation, whereas after 50 cycles (after being fully delithiated), the XRD data showed significant evidence of crystalline constituents of the SEI alongside the original monoclinic phase, which potentially helped the stable cycling performance.

\section{Conclusions}

Nano-sized mixed molybdenum-vanadium oxides were synthesised using a one-step continuous hydrothermal flow synthesis method. The mixed oxides crystallised in monoclinic structure and formed a single solid solution (across all compositions investigated) based either on a $\mathrm{VO}_{2}$ (potentially Mo-doped) or $\mathrm{MoO}_{2}$ (V-doped), except for one sample with nominal composition $\mathrm{Mo}_{0.5} \mathrm{~V}_{0.5} \mathrm{O}_{2}$ (which was a mixture of both solid solutions). This suggested that $\mathrm{Mo}_{0.5} \mathrm{~V}_{0.5} \mathrm{O}_{2}$ lies within the miscibility gap.

At a specific current of $0.1 \mathrm{~A} \mathrm{~g}^{-1}$, the specific capacities were ca. 350, 450 and $560 \mathrm{mAh} \mathrm{g}^{-1}$ for $\mathrm{VO}_{2}, \mathrm{Mo}_{0.33} \mathrm{~V}_{0.67} \mathrm{O}_{2}$ and $\mathrm{Mo}_{0.5} \mathrm{~V}_{0.5} \mathrm{O}_{2}$. For higher concentrations of molybdenum, the specific capacities were much worse, especially at high current rates. For $\mathrm{VO}_{2}$, the specific capacity was $90 \mathrm{mAh} \mathrm{g}^{-1}$ at a high specific current of $10 \mathrm{Ag}^{-1}$, whereas, for $\mathrm{Mo}_{0.5} \mathrm{~V}_{0.5} \mathrm{O}_{2}$ and $\mathrm{Mo}_{0.33} \mathrm{~V}_{0.67} \mathrm{O}_{2}$, specific capacities of ca. 200 and $160 \mathrm{mAh} \mathrm{g}^{-1}$, respectively, were observed under the same conditions. A comparison with $\mathrm{V}$ and Mo containing electrode materials from the literature can be seen in Fig. 9 showing excellent rate capability at $10 \mathrm{Ag}^{-1}$ likely arising from their nanoparticulate nature.

Due to large pseudocapacitive contributions to the overall 


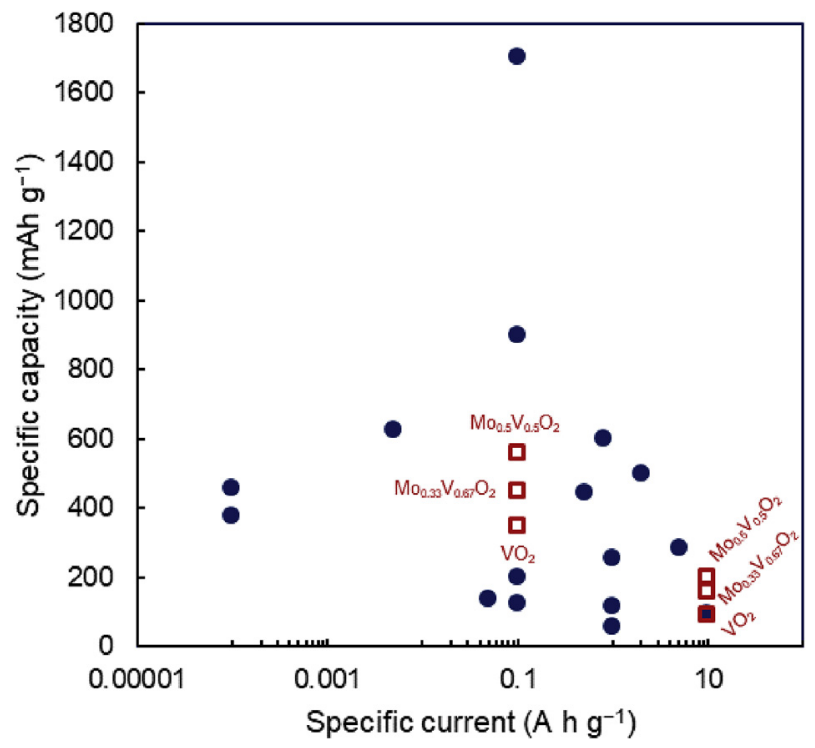

Fig. 9. Literature values (blue circles) for the specific current versus specific capacity of various $\mathrm{V}$ and Mo containing Li-ion electrodes taken from reference 25 to 32 . The best performing samples prepared in this publication are included for comparison (red squares). (For interpretation of the references to colour in this figure legend, the reader is referred to the Web version of this article.)

charge storage, the electrodes made from nominal compositions $\mathrm{Mo}_{0.33} \mathrm{~V}_{0.67} \mathrm{O}_{2}$ and $\mathrm{Mo}_{0.5} \mathrm{~V}_{0.5} \mathrm{O}_{2}$ showed excellent performance when cycled in Li-ion half-cells. The pseudocapacitive contributions were ca. $90 \%$ of the total charge for both samples at a scan rate of $10 \mathrm{mV} \mathrm{s}^{-1}$ and the pseudocapacitive charge (at a theoretically unlimited rate) was 712 and $825 \mathrm{Cg}^{-1}$ for $\mathrm{Mo}_{0.33} \mathrm{~V}_{0.67} \mathrm{O}_{2}$ and $\mathrm{Mo}_{0.5} \mathrm{~V}_{0.5} \mathrm{O}_{2}$, respectively.

In contrast to other vanadium oxides, molybdenum oxides and mixed molybdenum-vanadium oxides in the literature, the materials presented herein benefit not only from excellent performance at high current rates and good cyclability but also the one-step synthesis and scalability of the synthesis.

\section{Acknowledgements}

The EPSRC are thanked for funding the Centre for Doctoral Training in Molecular Modelling and Materials Science (UCL, UK). JAIST (Kanazawa, Japan) are thanked for supporting a studentship for DB. DJLB and PRS thank EPSRC for support of the ELEVATE (ELEctrochemical Vehicle Advanced TEchnology) low carbon vehicles project (EP/M009394/1). JAD thanks EPSRC for support of the Joint University Industry Consortium for Energy materials and Devices (JUICED) hub (EP/R023662/1). We thank the Diamond Light Source for the award of beam time as part of the Energy Materials Block Allocation Group SP14239.

\section{Appendix A. Supplementary data}

Supplementary data to this article can be found online at https://doi.org/10.1016/j.electacta.2019.134695.

\section{References}

[1] M. Armand, J.-M. Tarascon, Nature 451 (2008) 652-657.

[2] M.R. Palacín, Chem. Soc. Rev. 38 (2009) 2565-2575.

[3] M. Winter, R.J. Brodd, Chem. Rev. 104 (2004) 4245-4269.

[4] K. Tang, X. Mu, P.a. van Aken, Y. Yu, J. Maier, Adv. Energy Mater. 3 (2013) 49-53.

[5] P.G. Bruce, B. Scrosati, J.-M. Tarascon, Angew. Chem. Int. Ed. 47 (2008)
2930-2946.

[6] H.-S. Kim, J.B. Cook, S.H. Tolbert, B. Dunn, J. Electrochem. Soc. 162 (2015) A5083-A5090.

[7] I.D. Johnson, E. Blagovidova, P.A. Dingwall, D.J.L. Brett, P.R. Shearing, J.A. Darr, J. Power Sources 326 (2016) 476-481.

[8] M. Lübke, J. Shin, P. Marchand, D. Brett, P. Shearing, Z. Liu, J.A. Darr, D. Brett, Z. Liu, J.A. Darr, J. Mater. Chem. 3 (2015) 22908-22914.

[9] D. Bauer, A.J. Roberts, N. Matsumi, J.A. Darr, Nanotechnology 28 (2017) 195403.

[10] H. Liu, Z. Bi, X.-G. Sun, R.R. Unocic, M.P. Paranthaman, S. Dai, G.M. Brown, Adv. Mater. 23 (2011) 3450-3454.

[11] M. Lübke, N. Ding, M.J. Powell, D.J.L. Brett, P.R. Shearing, Z. Liu, J.A. Darr, Electrochem. Commun. 64 (2016) 56-60.

[12] D. Bauer, A.J. Roberts, C.L. Starkey, R. Vedarajan, D.J.L. Brett, P.R. Shearing, N. Matsumi, J.A. Darr, Int. J. Electrochem. Sci. 13 (2018) 5120-5140.

[13] T. Brousse, D. Belanger, J.W. Long, J. Electrochem. Soc. 162 (2015) A5185-A5189.

[14] Y. Shi, B. Guo, S.A. Corr, Q. Shi, Y.S. Hu, K.R. Heier, L. Chen, R. Seshadri, G.D. Stucky, Nano Lett. 9 (2009) 4215-4220.

[15] B. Guo, X. Fang, B. Li, Y. Shi, C. Ouyang, Y.S. Hu, Z. Wang, G.D. Stucky, L. Chen, Chem. Mater. 24 (2012) 457-463.

[16] Y. Sun, X. Hu, W. Luo, Y. Huang, J. Mater. Chem. 22 (2012) 425-431.

[17] J.H. Ku, Y.S. Jung, K.T. Lee, C.H. Kim, S.M. Oh, J. Electrochem. Soc. 156 (2009) A688.

[18] N.A. Chernova, M. Roppolo, A.C. Dillon, M.S. Whittingham, J. Mater. Chem. 19 (2009) 2526

[19] S.D. Perera, B. Patel, N. Nijem, K. Roodenko, O. Seitz, J.P. Ferraris, Y.J. Chabal, K.J. Balkus, Adv. Energy Mater. 1 (2011) 936-945.

[20] S. Li, Int. J. Electrochem. Sci. 13 (2018) 23-28.

[21] N. Chen, C. Wang, F. Hu, X. Bie, Y. Wei, G. Chen, F. Du, ACS Appl. Mater. Interfaces 7 (2015) 16117-16123.

[22] D. Zhao, J. Qin, L. Zheng, M. Cao, Chem. Mater. 28 (2016) 4180-4190.

[23] U. Kumar Sen, A. Shaligram, S. Mitra, ACS Appl. Mater. Interfaces 6 (2014) $14311-14319$

[24] F. Xia, X. Hu, Y. Sun, W. Luo, Y. Huang, Nanoscale 4 (2012) 4707.

[25] Y. Xu, R. Yi, B. Yuan, X. Wu, M. Dunwell, Q. Lin, L. Fei, S. Deng, P. Andersen, D. Wang, et al., J. Phys. Chem. Lett. 3 (2012) 309-314.

[26] D. Wu, R. Shen, R. Yang, W. Ji, M. Jiang, W. Ding, L. Peng, Sci. Rep. 7 (2017) 44697.

[27] C. Niu, J. Meng, C. Han, K. Zhao, M. Yan, L. Mai, Nano Lett. 14 (2014) 2873-2878.

[28] Y. Shi, S.L. Chou, J.Z. Wang, H.Z. Li, H.K. Liu, Y.P. Wu, J. Power Sources 244 (2013) 684-689.

[29] J.A. Darr, J. Zhang, N.M. Makwana, X. Weng, Chem. Rev. 117 (2017) $11125-11238$

[30] C.F. Armer, M. Lübke, I. Johnson, K. McColl, F. Cora, J.S. Yeoh, M.V. Reddy, J.A. Darr, X. Li, A. Lowe, J. Solid State Electrochem. 22 (2018) 3703-3716.

[31] Y. Xu, D. Bauer, M. Lübke, T.E. Ashton, Y. Zong, J.A. Darr, J. Power Sources 408 (2018) 28-37.

[32] I.D. Johnson, E. Blagovidova, P.A. Dingwall, D.J.L. Brett, P.R. Shearing, J.A. Darr, J. Power Sources 326 (2016) 476-481.

[33] I.D. Johnson, M. Lübke, O.Y. Wu, N.M. Makwana, G.J. Smales, H.U. Islam, R.Y. Dedigama, R.I. Gruar, C.J. Tighe, D.O. Scanlon, et al., J. Power Sources 302 (2016) 410-418

[34] I.D. Johnson, M. Loveridge, R. Bhagat, J.A. Darr, ACS Comb. Sci. 18 (2016) 665-672.

[35] I.D. Johnson, T.E. Ashton, E. Blagovidova, G.J. Smales, M. Lübke, P.J. Baker, S.A. Corr, J.A. Darr, Sci. Rep. 8 (2018) 4114.

[36] Q. Zhang, E. Uchaker, S.L. Candelaria, G. Cao, Chem. Soc. Rev. 42 (2013) 3127.

[37] P. Liu, Y. Xu, K. Zhu, K. Bian, J. Wang, X. Sun, Y. Gao, H. Luo, L. Lu, J. Liu, J. Mater. Chem. 5 (2017) 8307-8316.

[38] M. Chen, C.Y. Ma, T. Mahmud, J.A. Darr, X.Z. Wang, J. Supercrit. Fluids 59 (2011) 131-139.

[39] D. Bauer, A.J. Roberts, S.G. Patnaik, D.J.L. Brett, P.R. Shearing, E. Kendrick, N. Matsumi, J.A. Darr, J. Electrochem. Soc. 165 (2018) A1662-A1670.

[40] D.P. Howard, P. Marchand, L. McCafferty, C.J. Carmalt, I.P. Parkin, J.A. Darr, ACS Comb. Sci. 19 (2017) 239-245.

[41] R.I. Gruar, C.J. Tighe, J.A. Darr, Ind. Eng. Chem. Res. 52 (2013) 5270-5281.

[42] J.A. Darr, C.J. Tighe, R.I. Gruar, Co-Current Mixer, Apparatus, Reactor and Method for Precipitating Nanoparticles, 2013. US2013/0136687 A1.

[43] C.J. Denis, C.J. Tighe, R.I. Gruar, N.M. Makwana, J.A. Darr, Cryst. Growth Des. 15 (2015) 4256-4265.

[44] A.R. Denton, N.W. Ashcroft, Phys. Rev. A 43 (1991) 3161-3164.

[45] B. Solsona, M.I. Vázquez, F. Ivars, A. Dejoz, P. Concepción, J.M. López Nieto, J. Catal. 252 (2007) 271-280.

[46] F. Ivars, B. Solsona, S. Hernández, J.M. López Nieto, Catal. Today 149 (2010) $260-266$.

[47] B.O. Marinder, Mater. Res. Bull. 10 (1975) 909-914.

[48] M. Sathiya, A.S. Prakash, K. Ramesha, J.M. Tarascon, A.K. Shukla, J. Am. Chem. Soc. 133 (2011) 16291-16299.

[49] Y. Sun, X. Hu, W. Luo, Y. Huang, ACS Nano 5 (2011) 7100-7107.

[50] W. Ji, R. Shen, R. Yang, G. Yu, X. Guo, L. Peng, W. Ding, J. Mater. Chem. 2 (2014) 699-704.

[51] A. Katrib, J.W. Sobczak, M. Krawczyk, L. Zommer, A. Benadda, A. Jablonski, G. Maire, Surf. Interface Anal. 34 (2002) 225-229. 
[52] A.N. Mansour, P.H. Smith, W.M. Baker, M. Balasubramanian, J. McBreen, Electrochim. Acta 47 (2002) 3151-3161.

[53] T.E. Ashton, D. Hevia Borrás, A. Iadecola, K.M. Wiaderek, P.J. Chupas, K.W. Chapman, S.A. Corr, Acta Crystallogr. Sect. B Struct. Sci. Cryst. Eng. Mater. 71 (2015) 722-726.

[54] C. Brookes, M. Bowker, P. Wells, Catalysts 6 (2016) 92.

[55] C. Brookes, M. Bowker, E.K. Gibson, D. Gianolio, K.M.H. Mohammed, S. Parry, S.M. Rogers, I.P. Silverwood, P.P. Wells, Catal. Sci. Technol. 6 (2016) 722-730.

[56] Y. Wu, L. Fan, Q. Liu, S. Chen, W. Huang, F. Chen, G. Liao, C. Zou, Z. Wu, Sci. Rep. 5 (2015) $1-8$.

[57] M. Lv, W. Xie, S. Sun, G. Wu, L. Zheng, S. Chu, C. Gao, J. Bao, Catal. Sci. Technol. 5 (2015) 2925-2934.

[58] J. Majeed, C. Nayak, S.N. Jha, K. Bhattacharyya, D. Bhattacharyya, A.K. Tripathi, RSC Adv. 5 (2015) 90932-90940.

[59] A.G. Dylla, G. Henkelman, K.J. Stevenson, Acc. Chem. Res. 46 (2013) 1104-1112.

[60] V. Augustyn, J. Come, M.A. Lowe, J.W. Kim, P.-L. Taberna, S.H. Tolbert,
H.D. Abruña, P. Simon, B. Dunn, Nat. Mater. 12 (2013) 518-522.

[61] L. Wu, D. Buchholz, D. Bresser, L. Gomes Chagas, S. Passerini, J. Power Sources 251 (2014) 379-385.

[62] H. Xiong, M.D. Slater, M. Balasubramanian, C.S. Johnson, T. Rajh, J. Phys. Chem. Lett. 2 (2011) 2560-2565

[63] T.J. Patey, R. Büchel, M. Nakayama, P. Novák, Phys. Chem. Chem. Phys. 11 (2009) 3756.

[64] L. Guo, Y. Wang, J. Mater. Chem. 3 (2015) 4706-4715.

65] X.-Y. Xue, Z.-H. Chen, L.-L. Xing, S. Yuan, Y.-J. Chen, Chem. Commun. 47 (2011) 5205.

[66] Y. Luo, J. Luo, J. Jiang, W. Zhou, H. Yang, X. Qi, H. Zhang, H.J. Fan, D.Y.W. Yu, C.M. Li, et al., Energy Environ. Sci. 5 (2012) 6559.

[67] Y. Tang, D. Wu, Y. Mai, H. Pan, J. Cao, C. Yang, F. Zhang, X. Feng, Nanoscale 6 (2014) 14679-14685.

[68] X.H. Rui, N. Yesibolati, S.R. Li, C.C. Yuan, C.H. Chen, Solid State Ion. 187 (2011) $58-63$. 